\title{
Expression of S1P metabolizing enzymes and receptors correlate with survival time and regulate cell migration in glioblastoma multiforme
}

\author{
Sandra Bien-Möller ${ }^{1,2}$, Sandra Lange $^{1}$, Tobias Holm ${ }^{1}$, Andreas Böhm ${ }^{1}$, Heiko \\ Paland $^{1,2}$, Johannes Küpper ${ }^{1}$, Susann Herzog ${ }^{1,2}$, Kerstin Weitmann ${ }^{4}$, Christoph \\ Havemann ${ }^{4}$, Silke Vogelgesang ${ }^{3}$, Sascha Marx ${ }^{2}$, Wolfgang Hoffmann ${ }^{4}$, Henry W.S. \\ Schroeder', Bernhard H. Rauch ${ }^{1}$ \\ ${ }^{1}$ Department of Pharmacology, University Medicine Greifswald, Greifswald, Germany \\ ${ }^{2}$ Department of Neurosurgery, University Medicine Greifswald, Greifswald, Germany \\ ${ }^{3}$ Institute of Pathology, Department of Neuropathology, University Medicine Greifswald, Greifswald, Germany \\ ${ }^{4}$ Institute for Community Medicine, University Medicine Greifswald, Greifswald, Germany \\ Correspondence to: Sandra Bien-Möller, e-mail: sbien@uni-greifswald.de \\ Keywords: glioblastoma multiforme, sphingosine-1-phosphate, S1P receptor signaling \\ Received: August 03, 2015 \\ Accepted: January 27, 2016 \\ Published: February 13, 2016
}

\section{ABSTRACT}

A signaling molecule which is involved in proliferation and migration of malignant cells is the lipid mediator sphingosine-1-phosphate (S1P). There are hints for a potential role of S1P signaling in malignant brain tumors such as glioblastoma multiforme (GBM) which is characterized by a poor prognosis. Therefore, a comprehensive expression analysis of S1P receptors $\left(S_{1} P_{1}-S_{1} P_{5}\right)$ and S1P metabolizing enzymes in human GBM $(n=117)$ compared to healthy brain $(n=10)$ was performed to evaluate their role for patient's survival. Furthermore, influence of S1P receptor inhibition on proliferation and migration were studied in LN18 GBM cells. Compared to control brain, mRNA levels of $\mathrm{S1P}_{1}, \mathrm{S1P}_{2}, \mathrm{S1P}_{3}$ and S1P generating sphingosine kinase-1 were elevated in GBM. Kaplan-Meier analyses demonstrated an association between $S_{1 P_{1}}$ and $S_{1} P_{2}$ with patient's survival times. In vitro, an inhibitory effect of the SphK inhibitor SKI-II on viability of LN18 cells was shown. S1P itself had no effect on viability but stimulated LN18 migration which was blocked by inhibition of S1P $P_{1}$ and $\mathrm{S1P}_{2^{*}}$. The participation of $\mathrm{S} \mathrm{P}_{1}$ and $\mathrm{S}_{1} \mathrm{P}_{2}$ in LN18 migration was further supported by siRNA-mediated silencing of these receptors. Immunoblots and inhibition experiments suggest an involvement of the PI3-kinase/AKT1 pathway in the chemotactic effect of S1P in LN18 cells.

In summary, our data argue for a role of S1P signaling in proliferation and migration of GBM cells. Individual components of the S1P pathway represent prognostic factors for patients with GBM. Perspectively, a selective modulation of S1P receptor subtypes could represent a therapeutic approach for GBM patients and requires further evaluation.

\section{INTRODUCTION}

The glioblastoma multiforme (GBM) is the most common primary brain tumor in adults. Despite an adjuvant radiochemotherapy in addition to surgery, the GBM is characterized by rapid tumor recurrence resulting in a poor prognosis with a median survival time of only 12 to 15 months $[1,2]$. To date, no groundbreaking improvements in the therapeutic management of GBM have been achieved. As underlying reasons for relapses of GBM the resistance of glioma stem-like cells against the current therapy as well as the migration and invasion of GBM cells into adjacent brain regions are discussed [3]. A signaling molecule which is involved in proliferation, migration and invasion of a broad range of healthy and malignant cells is the sphingosine-1-phosphate (S1P) [4]. S1P is formed intracellularly from sphingosine in a reaction catalyzed 
by the two isoenzymes sphingosine kinase 1 and 2 (SphK1/2) [5]. The S1P phosphatases 1 and 2 (SGPP1/2) dephosphorylate S1P back to sphingosine whereas the S1P lyase (SGPL) mediates the irreversible cleavage to hexadecenal and phosphoethanolamine [6, 7]. Neurons and astrocytes can constitutively export S1P which supports the hypothesis that cells of the nervous system can be an origin of extracellular S1P $[8,9]$. Beside its intracellular actions, the autocrine and paracrine effects of S1P are mediated by a family of five G-protein coupled receptors $\left(\mathrm{S}_{1} \mathrm{P}_{1}-\mathrm{S}_{1} \mathrm{P}_{5}\right)$ which display tissue specific expression patterns with overlapping functions but also with some opposite effects $[4,10]$. They signal via $\mathrm{G}_{\mathrm{i} / \mathrm{o}}\left(\mathrm{S} 1 \mathrm{P}_{1}, \mathrm{~S} 1 \mathrm{P}_{2}\right.$ and $\left.\mathrm{S}_{\mathrm{P}}\right), \mathrm{G}_{\mathrm{q}}\left(\mathrm{S} 1 \mathrm{P}_{2}\right.$ and $\left.\mathrm{S} 1 \mathrm{P}_{3}\right)$, and $\mathrm{G}_{12 / 13}\left(\mathrm{~S} 1 \mathrm{P}_{2}, \mathrm{~S} 1 \mathrm{P}_{3}\right.$, and $\left.\mathrm{S} 1 \mathrm{P}_{5}\right)$ proteins particularly to the Ras/ERK, PI3K/Akt, and Rho/Rock signaling pathways [10]. The specific signaling pathways utilized by S1P and the biological consequences depend on the cellular expression levels of the respective $\mathrm{S} 1 \mathrm{P}$ receptor subtypes. Since S1P circulates in blood and lymphatic systems, it gains access to its receptors far away from the site of synthesis. Increased generation of S1P stimulates cell survival and malignant transformation, and regulates apoptosis, invasion, angiogenesis as well as hypoxia [4, 11-13]. Numerous studies have shown that SphK and S1P act as oncogenes in various tumors including lung, colon, breast, ovary, brain, stomach, uterus and kidney $[13,14]$. Furthermore, an attenuation of tumor progression in murine xenograft and allograft models through administration of a specific S1P targeted monoclonal antibody was demonstrated [15].

In GBM the $\mathrm{S} 1 \mathrm{P}$ receptors $\mathrm{S}_{1} \mathrm{P}_{1}, \mathrm{~S}_{\mathrm{P}}, \mathrm{S}_{2}, \mathrm{P}_{3}$ and $\mathrm{S}_{1} \mathrm{P}_{5}$ are found to be overexpressed whereas $\mathrm{S}_{1} \mathrm{PR}_{4}$ is missing in GBM cells [16]. S1P levels also are strongly elevated in GBM tissue compared to non-malignant brain [17] and glioma cell lines are able to release S1P into the extracellular space [18]. The GBM stem cell survival and the regulation of a characteristic phenotypic stem cell profile also seems to involve S1P signaling [19-21] and the sphingosine analogue FTY720 (fingolimod) slowed growth of intracranial xenograft tumors in nude mice and augmented the therapeutic effect of temozolomide [22], the standard chemotherapeutic compound for treatment of patients with GBM. Thus, several studies argue for a potential role of S1P signaling in GBM growth and progress but the existing data concerning the impact of $\mathrm{S} 1 \mathrm{P}$ in GBM cell proliferation and migration partly differ in their conclusions [23-27].

This study represents a comprehensive analysis of the expression of S1P receptors and enzymes involved in $\mathrm{S} 1 \mathrm{P}$ metabolism in human GBM samples in comparison to healthy tissue specimens and evaluated their role for patient's survival. Furthermore, the effects of S1P receptor inhibition and siRNA mediated knockdown on viability and migration as well as underlying signaling pathways were analyzed in LN18 GBM cells.

\section{RESULTS}

\section{Expression of S1P receptors and S1P metabolizing enzymes in GBM and impact on patient's survival}

Expression of S1P receptors and S1P metabolizing enzymes in GBM specimens was analyzed in comparison to non-malignant brain by quantitative RT-PCR. As seen in Figure 1, the mRNA expression levels of $\mathrm{S}_{1} \mathrm{P}_{1}, \mathrm{~S}_{1} \mathrm{P}_{2}$ and $\mathrm{S}_{1} \mathrm{P}_{3}$ were significantly up-regulated compared to control brain from 0.88 to $4.23\left(\mathrm{~S} 1 \mathrm{P}_{1}\right)$, from 0.19 to 24.78 $\left(\mathrm{S}_{\mathrm{P}} \mathrm{P}_{2}\right)$ and from 0.79 to $4.51\left(\mathrm{~S}_{\mathrm{P}}\right)$ fold, respectively. In contrast, for $\mathrm{S}_{1} \mathrm{P}_{5}$ mRNA a slight down-regulation from 0.77 to 0.49 fold was observed in GBM specimens, and ${\mathrm{S} 1 \mathrm{P}_{4}}_{4}$ expression was below the detection limit.

Concerning the S1P metabolizing enzymes, only the mRNA expression of the S1P generating enzyme SphK1 was significantly up-regulated in GBM compared to control brain from 1.31 to 3.18 fold. Expression of SphK2 as well as of the S1P degrading enzymes SGPP1/2 and SGPL1 in GBM was not significantly altered in comparison to that in non-malignant brain.

Interestingly, subdividing our patient cohort into primary tumors and relapses revealed no significant differences in the expression of S1P receptors or the S1P metabolizing enzymes (Supplementary Figure S1A-S1I).

To investigate whether expression of S1P receptors and S1P metabolizing enzymes has any impact on the survival of patients with GBM we performed KaplanMeier analyses. Using the median gene expression the GBM patients were subdivided in two groups: < median versus $>=$ median expression. As seen in Figure 2A and $2 \mathrm{~B}, \mathrm{~S}_{1} \mathrm{P}_{1}$ and $\mathrm{S}_{1} \mathrm{P}_{2}$ expression was significantly associated with the survival time of GBM patients. Interestingly, for $\mathrm{S}_{1} \mathrm{P}_{1}$ a positive association with the patients' survival was observed. Patients with a high $\mathrm{S}_{1} \mathrm{P}_{1}$ mRNA expression ( $>=$ median) showed a prolonged survival compared to patients with a low $\mathrm{S} 1 \mathrm{P}_{1}$ mRNA expression ( $<$ median, hazard ratio 2.77 ). In contrast, $\mathrm{S}_{1} \mathrm{P}_{2}$ mRNA expression negatively correlated with the survival time of GBM patients. Patients with a high $\mathrm{S}_{1} \mathrm{P}_{2}$ mRNA expression ( $>=$ median) had a worse survival in comparison to patients with a low $\mathrm{S}_{1} \mathrm{P}_{2}$ expression ( $<$ median, hazard ratio 0.56). Similarly, a high expression of S1P dephosphorylating SGPP1 $(>=$ median) was associated with a poor survival compared to a low SGPP1 mRNA expression (< median, hazard ratio 0.47 , Figure $2 \mathrm{G}$ ). In contrast, expression of $\mathrm{S}_{1} \mathrm{P}_{3}, \mathrm{~S}_{1} \mathrm{P}_{5}$, SphK1 and 2, SGPP2 or SGPL1 showed no association with the survival time of patients with GBM.

The observed prognostic relevance of $\mathrm{S}_{1} \mathrm{P}_{1}$ and $\mathrm{S}_{1} \mathrm{P}_{2}$ expression was maintained when the ratio between $\mathrm{S}_{1} \mathrm{P}_{1}$ and $\mathrm{S} 1 \mathrm{P}_{2}$ expression $\left(\mathrm{S}_{1} \mathrm{P}_{1} / \mathrm{S}_{1} \mathrm{P}_{2}\right)$ was used for survival analysis (hazard ratio 2.38, Supplementary Figure S2A). In addition, a moderate but significant negative correlation 
between $\mathrm{S}_{1} \mathrm{P}_{1}$ and $\mathrm{S}_{1} \mathrm{P}_{2}$ expression in GBM samples was seen (Spearman $r-0.374, p=0.0045$, Supplementary Figure S2B). The subdivision of GBM patients in four subgroups according to high $(>=$ median) and/or low ( $<$ median) $\mathrm{S}_{1} \mathrm{P}_{1}$ and $\mathrm{S}_{1} \mathrm{P}_{2}$ expression is shown in Supplementary Figure S2C-S2H. It was recognizable that the highest prognostic impact with a hazard ratio of 3.89 and a significantly prolonged survival was seen for the subgroup of GBM patients with a high expression of S1P combined with a low expression of $\mathrm{S} \mathrm{P}_{2}$ (Supplementary Figure S2H).
The combined survival analysis with the ratio between $\mathrm{S}_{1} \mathrm{P}_{1}$ and $\mathrm{SGPP} 1\left(\mathrm{~S}_{1} \mathrm{P}_{1} / \mathrm{SGPP} 1\right)$ resulted in similar curves as seen for $\mathrm{S}_{1} \mathrm{P}_{1} / \mathrm{S}_{1} \mathrm{P}_{2}$, with a hazard ratio of 2.77 and a prolonged survival of patients with a high $\mathrm{S} 1 \mathrm{P}_{1} / \mathrm{SGPP} 1$ ratio $(<$ median, Supplementary Figure $\mathrm{S} 3 \mathrm{~A}$ ). In contrast to $\mathrm{S}_{1} \mathrm{P}_{1}$ and $\mathrm{S}_{1} \mathrm{P}_{2}$, there was no correlation between the expression of $\mathrm{S}_{1} \mathrm{P}_{1}$ and SGPP1 (Supplementary Figure S3B). Interestingly, the highest hazard ratio of all survival analyses with a value of 5.76 and a significantly prolonged survival time was found for the subgroup with a high expression
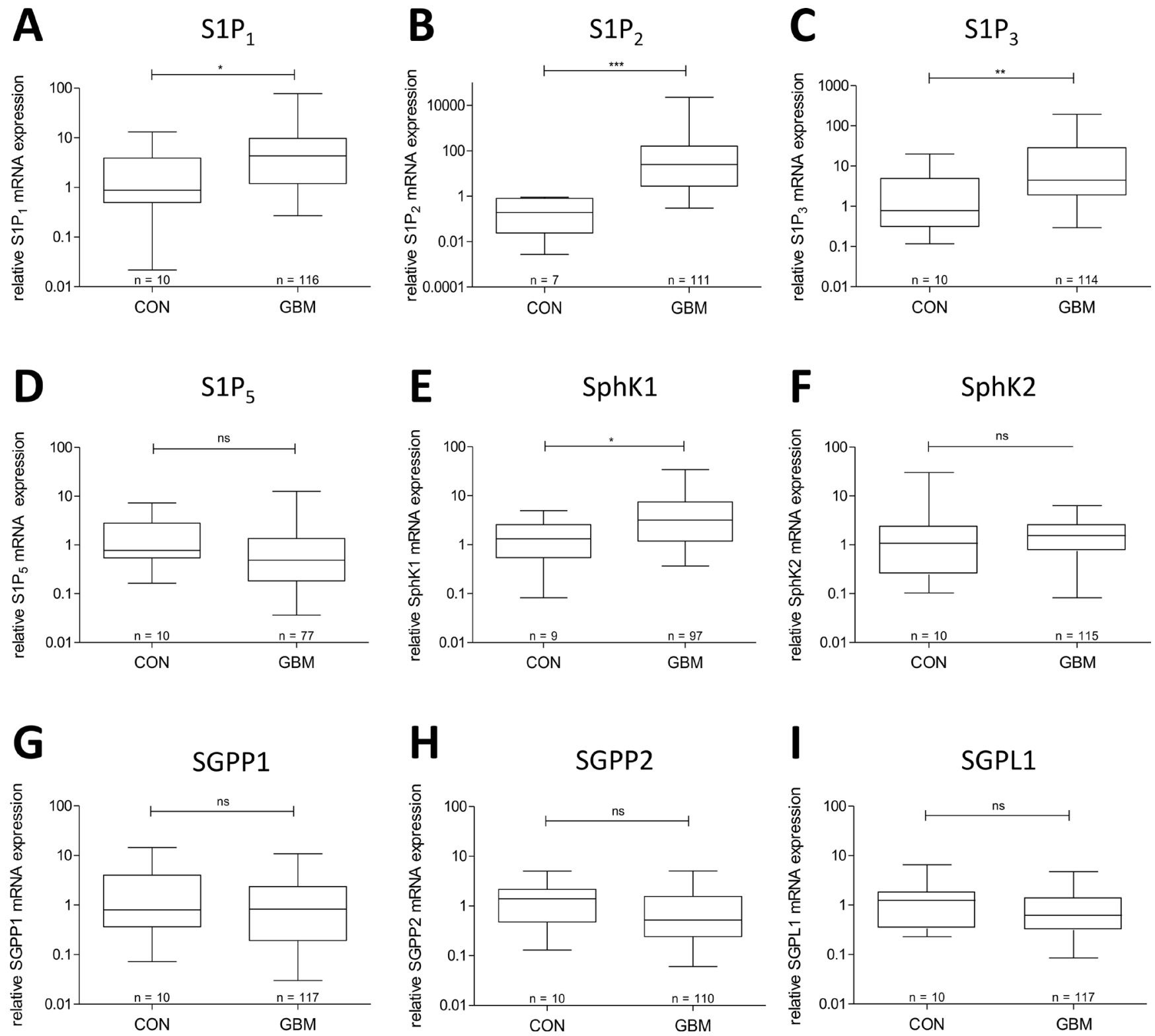

Figure 1: mRNA expression of $\mathrm{S} 1 \mathrm{P}$ receptors and $\mathrm{S} 1 \mathrm{P}$ metabolizing enzymes in glioblastoma tissue in comparison to non-malignant brain. (A) $\mathrm{S}_{1} \mathrm{P}_{1}$ mRNA expression, (B) $\mathrm{S}_{2} \mathrm{P}_{2}$ mRNA expression, (C) $\mathrm{S}_{1} \mathrm{P}_{3}$ mRNA expression, (D) S1P ${ }_{5}$ mRNA expression, (E) SphK1 mRNA expression, (F) SphK2 mRNA expression, (G) SGPP1 mRNA expression, (H) SGPP2 mRNA expression, (I) SGPL1 mRNA expression. mRNA expression levels in frontal/temporal lobes of non-neoplastic brains (CON) and glioblastoma patient's samples (GBM) were analyzed by quantitative RT-PCR with normalization to $18 \mathrm{~S}$ rRNA in relation to the median of CON. Data are shown as box plots representing the median as horizontal bars as well as the 5th and 95th percentile. Mann Whitney $U$ test, ns $=$ not significant, $* p<0.05, * * p<0.005$ and $* * * p<0.001$. 
of $\mathrm{S}_{1} \mathrm{P}_{1}$ in combination with a low expression of SGPP1 (Supplementary Figure $\mathrm{S} 3 \mathrm{H}$ ) arguing for the use of the $\mathrm{S} 1 \mathrm{P}_{1} / \mathrm{SGPP} 1$ ratio as best prognostic factor.

In addition, the simultaneous evaluation of $\mathrm{S}_{2} \mathrm{P}_{2}$ and SGPP1, which have a similar impact on survival of GBM patients (Figure $2 \mathrm{~B}$ and $2 \mathrm{G}$ ), with using the $\mathrm{S}_{2} \mathrm{P}_{2} /$ SGPP1 ratio for survival analysis revealed no deviations in the compared curves (Supplementary Figure S4A). This is in line with the positive correlation between $\mathrm{S}_{1} \mathrm{P}_{2}$ and SGPP1 expression in GBM samples (Supplementary Figure S4B). Furthermore, a high hazard ratio with a value of 4.56 was seen for the subgroup with a high expression

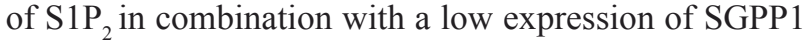
(Supplementary Figure S4H).

Beside glioblastoma patient samples, we isolated glioblastoma cells from freshly resected tumor tissue of three different patients and analyzed the expression of $\mathrm{S} 1 \mathrm{P}_{1-5}$, SphK1 and 2, SGPP1 and 2 as well as SGPL1 by quantitative RT-PCR. This was also performed in the human GBM cell lines LN18 and U87MG to compare and evaluate whether the tumor cells itself express all components of S1P signaling. As seen in Figure 3E, mRNA expression of SphK1/2, SGPP1 (but not SGPP2) and SGPL1 was detectable in the human cell lines LN18
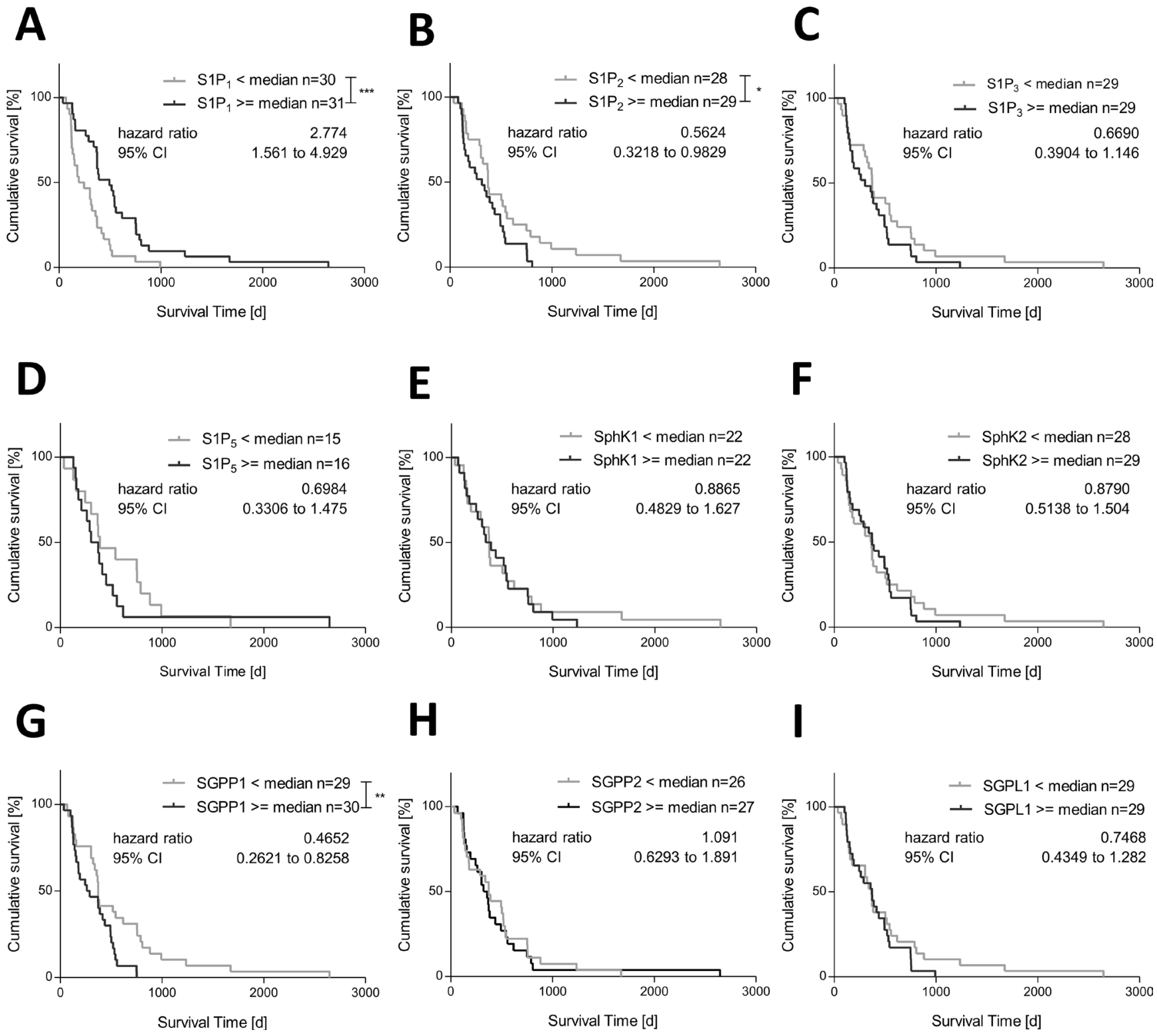

Figure 2: Association between mRNA expression of S1P receptors and S1P metabolizing enzymes and survival time of patients with glioblastoma multiforme. Kaplan-Meier survival curves for patients with glioblastoma multiforme based on their (A) $\mathrm{S}_{1} \mathrm{P}_{1}$ mRNA expression, (B) $\mathrm{S}_{\mathrm{P}} \mathrm{P}_{2}$ mRNA expression, (C) $\mathrm{S}_{1} \mathrm{P}_{3}$ mRNA expression, (D) $\mathrm{S}_{\mathrm{P}} \mathrm{P}_{5}$ mRA expression, (E) SphK1 mRNA expression, (F) SphK2 mRNA expression, (G) SGPP1 mRNA expression, (H) SGPP2 mRNA expression and (I) SGPL1 mRNA expression. Patients were divided into two subgroups depending on the respective median gene expression as determined by quantitative RT-PCR. Calculation of Hazard Ratios (< Median vs. $>=$ Median expression), Log-rank (Mantel-Cox) test, ${ }^{*} p<0.05, * * p<0.005$ and ${ }^{* * *} p<0.001$. 
and U87MG as well as in primary GBM cells (pGBM). Concerning $\mathrm{S} 1 \mathrm{P}$ receptors, $\mathrm{S}_{1} \mathrm{P}_{1-3}$ and $\mathrm{S}_{1} \mathrm{P}_{5}$ are present in both GBM cell lines and primary cells (Figure 3D).

\section{Influence of S1P signaling on viability of LN18 GBM cells in vitro}

For in vitro experiments we used the human GBM cell line LN18 which exhibits high mRNA expression levels of $\mathrm{S}_{1} \mathrm{P}_{3}$ and $\mathrm{S}_{1} \mathrm{P}_{5}$ and a lower expression of $\mathrm{S}_{1} \mathrm{P}_{1}$ and $\mathrm{S}_{1} \mathrm{P}_{2}$ whereas $\mathrm{S}_{1} \mathrm{P}_{4}$ was not found to be expressed (Figure 3A). This is consistent with the reported absence of $\mathrm{S}_{1} \mathrm{P}_{4}$ in GBM cells [16]. Expression of the S1P generating enzyme SphK1 in LN18 cells was determined by using immunofluorescence microscopy (Figure 3B). Furthermore, SphK1 protein expression was also strongly detectable by immunoblot analysis in the LN18 and U87MG cell lines as well as in one of the two investigated primary GBM cells (pGBM\#1, Figure 3C).

Treatment of LN18 cells with different S1P concentrations $(0.01$ to $5 \mu \mathrm{M})$ for $16 \mathrm{~h}$ or $48 \mathrm{~h} \mathrm{did}$ not result in any significant changes of cell viability (Figure 3F). In contrast, inhibition of SphK1/2 by SKIII significantly reduced cell viability of LN18 cells. As shown in Figure 3G (left panel) 10 and $25 \mu \mathrm{M}$ SKI-II significantly attenuated the viability of LN18 cells after $16 \mathrm{~h}$ to $86.1 \%$ and $61.9 \%$, respectively. The effect of SKIII on cell viability was greatly pronounced after $48 \mathrm{~h}$ by SKI-II concentrations of $5 \mu \mathrm{M}, 10 \mu \mathrm{M}$ or $25 \mu \mathrm{M}$ SKIII reducing cell viability to $59.6 \%, 45.0 \%$ and $19.9 \%$ (Figure $3 \mathrm{G}$ right panel). Even $2.5 \mu \mathrm{M}$ SKI-II significantly reduced cell viability of LN18 cells to $84.5 \%$ compared with control cells. In comparison, inhibition of $\mathrm{S}_{1} \mathrm{P}_{1}$ or $\mathrm{S}_{1} \mathrm{P}_{2}$ by the compounds W146 or JTE-013 significantly reduced cell viability of LN18 cells to $80.4 \%$ and $83.3 \%$, respectively, only after $48 \mathrm{~h}$ and at the highest concentration of $10 \mu \mathrm{M}$ (Figure $3 \mathrm{H}$ and 3I). Incubation of LN18 cells with the $\mathrm{S}_{1} \mathrm{P}_{3}$ inhibitor CAY10444 at comparable concentrations did not affect the cell viability (Figure 3J).

\section{Influence of S1P signaling on migration of LN18 GBM cells}

Migration of LN18 cells was investigated with the scratch wound healing assay $(16 \mathrm{~h})$ and the Boyden chamber assay ( $3 \mathrm{~h}$ ). As demonstrated in Figure 4A and $4 \mathrm{~B}$, incubation of LN18 cells with $1,2.5$ and $5 \mu \mathrm{M}$ S1P significantly stimulated the migration of LN18 cells in the wound healing assay to $169 \%, 179 \%$ and $156 \%$, respectively, compared to control cells. This pro-migratory effect of S1P was also seen in the Boyden chamber assay with a maximum effect of $207 \%$ at $2.5 \mu \mathrm{M} \mathrm{S1P}$ (Figure 4C and 4D). Conversely, inhibition of SphK by SKI-II (5 and $10 \mu \mathrm{M}$ ) resulted in a significantly reduced migration of LN18 cells to about $70 \%$ in the wound healing assay
(Figure 4E and 4F). Again, this effect was confirmed in the Boyden chamber assay with migration values of $75 \%$ and $59.6 \%$ for 5 and $10 \mu \mathrm{M}$ SKI-II, respectively (Figure $4 \mathrm{G}$ and $4 \mathrm{H})$. In comparison, temozolomide as the standard chemotherapeutic agent for the treatment of GBM did not cause any alterations in the migration of LN18 cells.

Further studies investigated the influence of S1P receptor inhibitors on GBM cell migration. As seen in Figure $5 \mathrm{~A}$ and $5 \mathrm{~B}$, the S1P-induced increase in LN18 cell migration to $148 \%(2.5 \mu \mathrm{M} \mathrm{S} 1 \mathrm{P})$ was significantly reduced almost to control level by both inhibition of $\mathrm{S}_{1} \mathrm{P}_{1}$ with W146 and by blocking $\mathrm{S}_{1} \mathrm{P}_{2}$ with JTE-013 $(10 \mu \mathrm{M}$, respectively) indicating that stimulation of both $\mathrm{S}_{1} \mathrm{P}_{1}$ and $\mathrm{S}_{1} \mathrm{P}_{2}$ is involved in the pro-migratory effect of

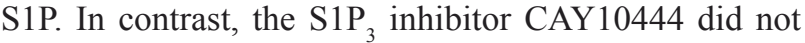
significantly block S1P induced cell migration. Using the Boyden chamber assay, the inhibitory effect of W146 and JTE-013 was confirmed, but interestingly inhibition of S1P ${ }_{3}$ by CAY10444 also significantly diminished S1P induced migration of LN18 cells which differs from the results of the wound healing assay. Potentially, a role of $\mathrm{S}_{1} \mathrm{P}_{3}$ particularly for cell adhesion to the collagen coated membrane or the different time scale compared to the wound healing assay may account for this difference in the effects of $\mathrm{S}_{1} \mathrm{P}_{3}$ inhibition in the transmigration assay.

To analyze whether $\mathrm{G}_{\mathrm{i} / \mathrm{o}}$ protein or $\mathrm{G}_{12 / 13}$ and ROCK protein dependent action is responsible for the S1P receptor mediated effects, we treated LN18 cells with Pertussis Toxin (PTX) to inhibit $\mathrm{G}_{\mathrm{i} / \mathrm{o}}$ protein signaling or with the ROCK inhibitor Y27632. Treatment with Y27632 reverted the S1P induced LN18 cell migration to the control level whereas inhibition of $\mathrm{G}_{\mathrm{i} / \mathrm{o}}$ protein signaling by PTX reduced the pro-migratory effect of S1P to a much lesser and non-significant extent (Figure 5C and 5D).

To confirm the specific impact of the S1P receptor inhibitors on migration of GBM cells, we performed siRNA-mediated silencing of $\mathrm{S}_{1} \mathrm{P}_{1}, \mathrm{~S}_{1} \mathrm{P}_{2}$ and $\mathrm{S}_{1} \mathrm{P}_{3}$ in LN18 cells. Compared to LN18 cells transfected with nonspecific control siRNA, the mRNA levels of $\mathrm{S}_{1} \mathrm{P}_{1}, \mathrm{~S}_{1} \mathrm{P}_{2}$ and $\mathrm{S}_{1} \mathrm{P}_{3}$ were significantly reduced by the respective receptor-specific siRNA constructs (Figure 5E) while the other receptor subtypes were not significantly influenced (Supplementary Figure S5). Using the Boyden chamber assay (Figure 5F and 5G), we found that the S1P-mediated increase in migration of LN18 cells was significantly reduced from $176 \%(2.5 \mu \mathrm{M} \mathrm{S} 1 \mathrm{P})$ to $65 \%$ and $85 \%$, when $\mathrm{S}_{1} \mathrm{P}_{1}$ or $\mathrm{S}_{1} \mathrm{P}_{2}$ were silenced, respectively. In comparison, the siRNA-mediated knockdown of $\mathrm{S}_{1} \mathrm{P}_{3}$ did not cause a statistically significant decrease of cell migration.

\section{Analysis of the intracellular signaling pathway responsible for S1P-mediated cell migration}

To reveal which signaling pathways may be responsible for the S1P-mediated migration of LN18 GBM cells, we blocked known S1P-induced signaling pathways 

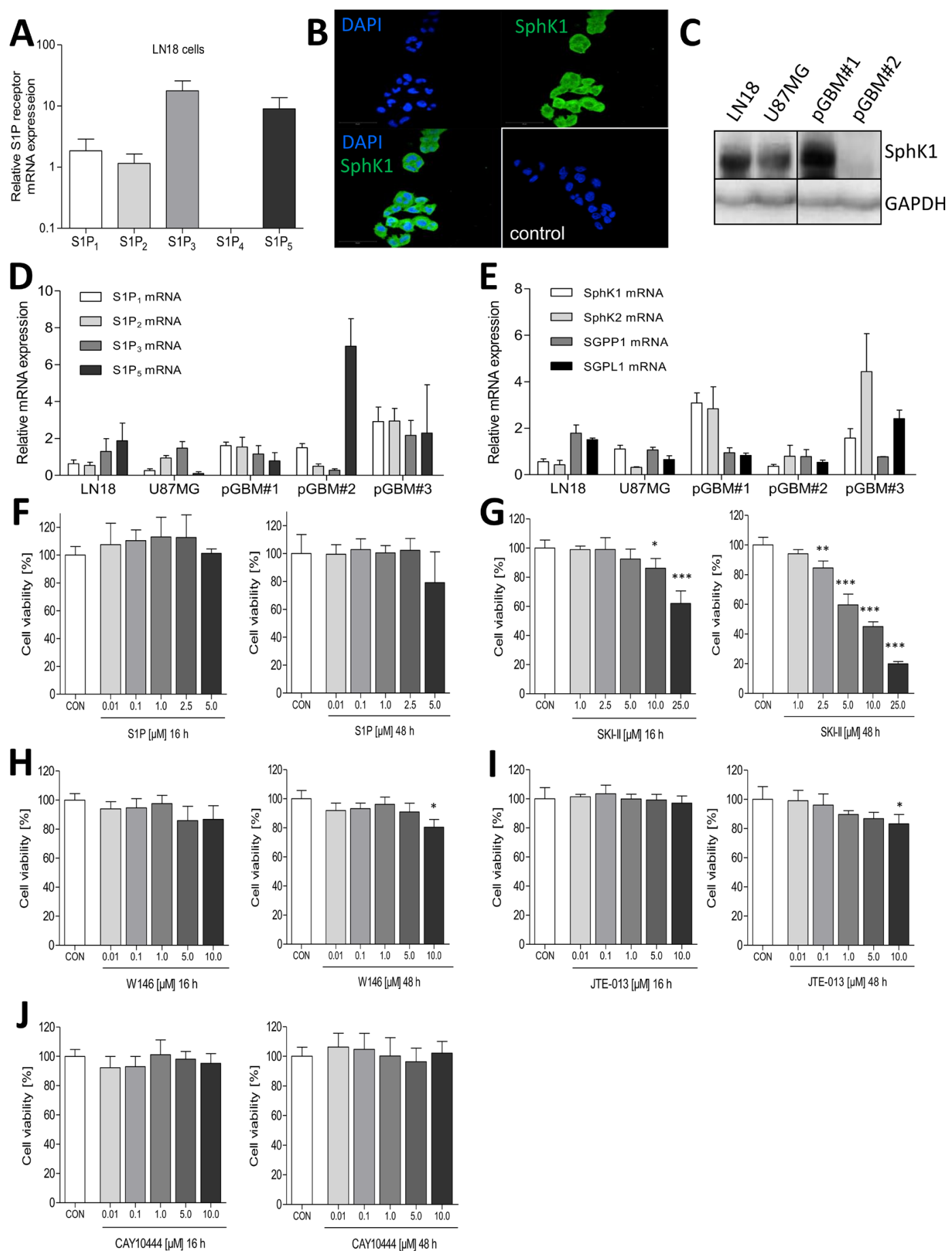

Figure 3: Analysis of the expression of $\mathrm{S} 1 \mathrm{P}$ receptors as well as of $\mathrm{S1P}$ metabolizing enzymes and influence of its pharmacological blocking on cell viability of LN18 GBM cells. (A) Relative mRNA expression of S1P receptors S1P, $\mathrm{S}_{1} \mathrm{P}_{2}$, $\mathrm{S}_{1} \mathrm{P}_{3}, \mathrm{~S}_{1} \mathrm{P}_{4}$ and $\mathrm{S}_{1} \mathrm{P}_{5}$ in the human LN18 GBM cell line determined by quantitative RT-PCR. (B) Immunofluorescence staining of the SphK1 in the human LN18 GBM cell line. The control (bottom right corner) represents LN18 cells stained only with the secondary AlexaFluor 488 coupled antibody without prior incubation with the primary anti-SphK1 antibody. (C) Immunoblot analysis of SphK1 protein expression in the human GBM cell lines LN18 and U87MG as well as in primary GBM cells (pGBM) isolated from fresh tumor samples. (D + E) Quantitative RT-PCR of (D) S1P receptors and (E) S1P metabolizing enzymes in the human GBM cell lines LN18 and U87MG as well as in primary GBM cells (pGBM) isolated from fresh tumor samples. (F-J). Determination of LN18 cell viability by using the resazurine assay after treatment with (C) S1P $(0.01,0.1,1,2.5$ and $5 \mu \mathrm{M})$, (D) sphingosine kinase inhibitor SKI-II (1, 2.5,10 and $25 \mu \mathrm{M})$, (E) the S1P receptor antagonist W146 $(0.01,0.1,1,5$ and $10 \mu \mathrm{M}),(\mathrm{F})$ the S1P ${ }_{2}$ receptor antagonist JTE-013 $(0.01,0.1,1,5$ and $10 \mu \mathrm{M})$ or $(\mathrm{G})$ the S1P ${ }_{3}$ receptor antagonist CAY10444 (0.01, 0.1, 1, 5 and $10 \mu \mathrm{M})$ for 16 (left panel) or $48 \mathrm{~h}$ (right panel). Control cells (CON) were treated with the respective solvent ( $\mathrm{MeOH}$ for S1P, DMSO for all inhibitors). Cell viability is shown in relation to the control $(100 \%)$, mean values and $\mathrm{SD}, n=3$, One-way analysis of variance with Dunnett's multiple comparison test, ${ }^{*} p<0.05,{ }^{* *} p<0.005$ and ${ }^{* * *} p<0.001$ vs. control. 
A

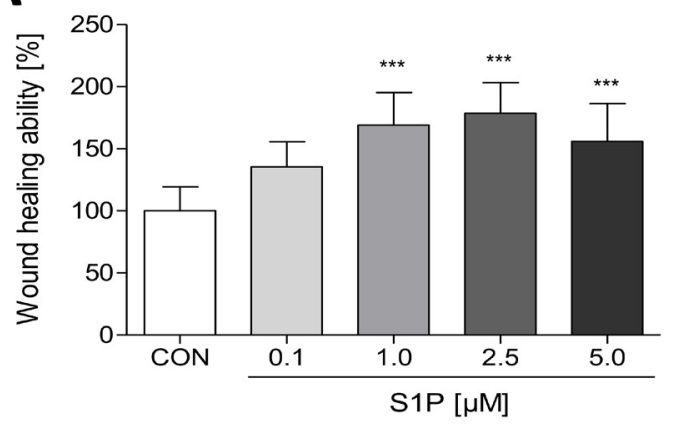

C

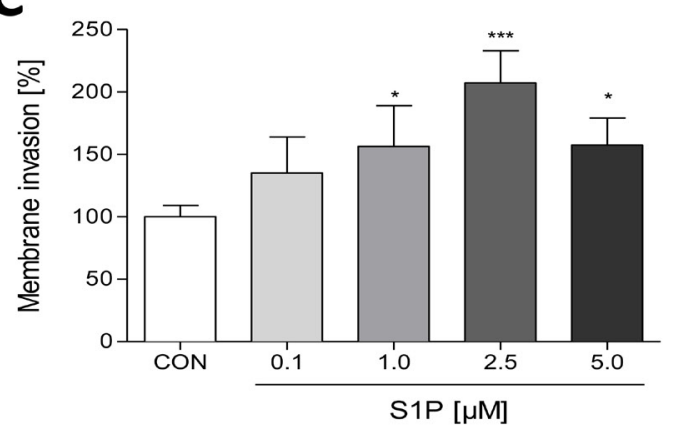

E

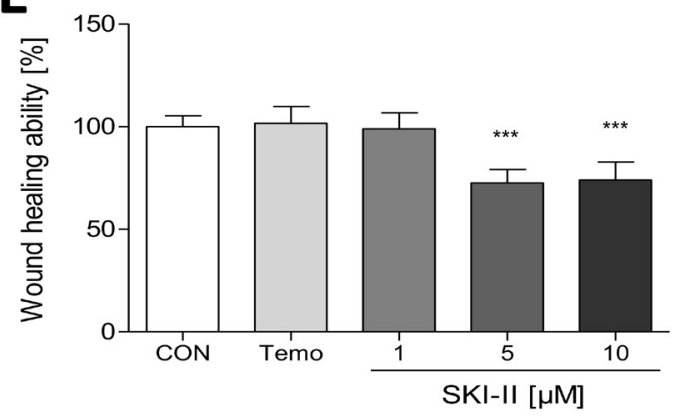

G

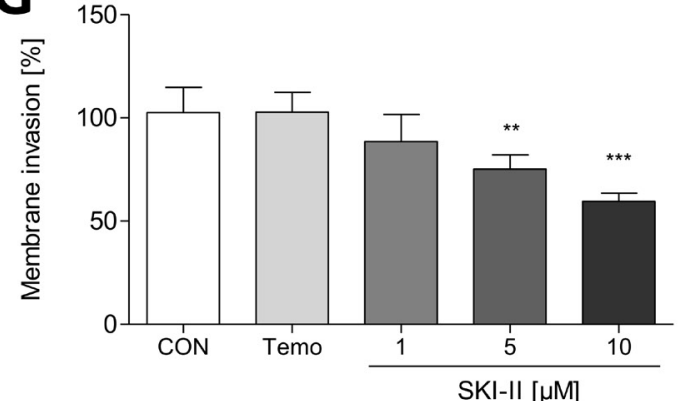

B

$\mathrm{Oh}$
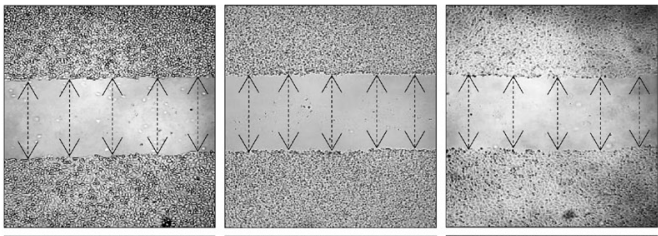

$16 \mathrm{~h}$

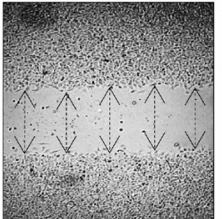

control
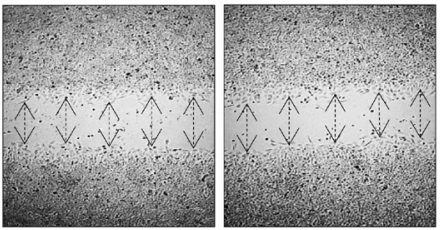

$2.5 \mu \mathrm{M} \mathrm{S1P}$

D

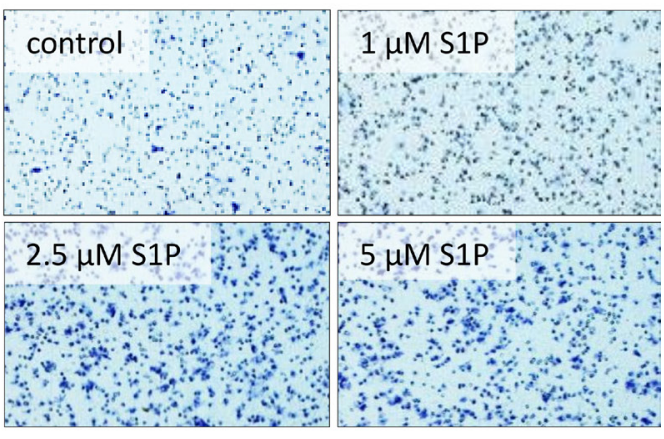

F

$\mathrm{oh}$

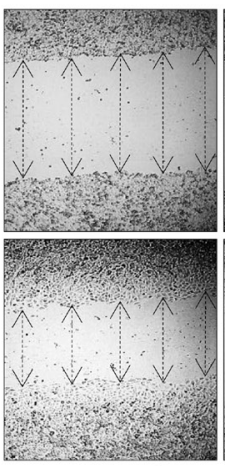

control

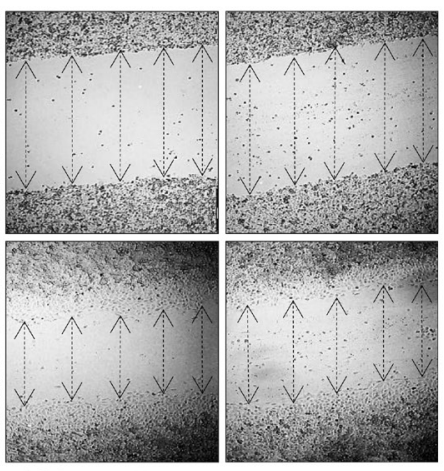

$100 \mu \mathrm{M}$ Temo

5 मM SKI-II

H

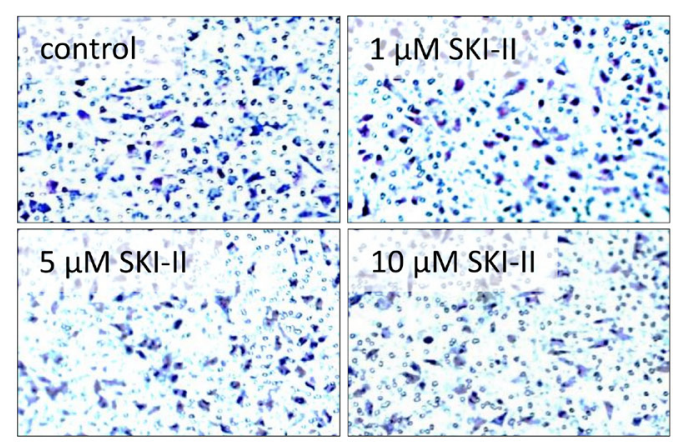

Figure 4: Influence of S1P, temozolomide and SKI-II on migration of LN18 GBM cells. $($ A + B, E + F) Analysis of LN18 cell migration using the wound closure assay with setting a scratch into the cell layer and measurement of the wound width at the beginning of the experiment $(0 \mathrm{~h})$ and $16 \mathrm{~h}$ after treatment with S1P $(\mathrm{A}+\mathrm{B} ; 0.1,1,2.5$ and $5 \mu \mathrm{M})$ and temozolomide $(\mathrm{E}+\mathrm{F}$; Temo, $100 \mu \mathrm{M})$ or SKI-II $(\mathrm{E}+\mathrm{F} ; 1,5$ and $10 \mu \mathrm{M})$. (A+E) Wound closure ability is shown in relation to the control $(\mathrm{CON}, 100 \%)$, mean values and $\mathrm{SD}, n=3$, Oneway analysis of variance with Dunnett's multiple comparison test, ${ }^{* * *} p<0.001$ vs. control. (B $\left.+\mathrm{F}\right)$ Representative images of the wound width at $0 \mathrm{~h}$ and $16 \mathrm{~h}$, the wound width is marked by arrows. $(\mathrm{C}+\mathrm{D}, \mathbf{G}+\mathbf{H})$ Analysis of LN18 cell migration using the Boyden chamber assay. Cells were treated for $3 \mathrm{~h}$ with $(\mathrm{C}+\mathrm{D}) \mathrm{S} 1 \mathrm{P}(0.1,1,2.5$ and $5 \mu \mathrm{M})$ and $(\mathrm{G}+\mathrm{H})$ temozolomide $($ Temo, $100 \mu \mathrm{M})$ or SKI-II $(1,5$ and $10 \mu \mathrm{M})$, fixed on the lower side of the membrane, stained with crystal violet and counted. (C+G) Counted cells are shown in relation to the control (CON, $100 \%)$, mean values and $\mathrm{SD}, n=3$, One-way analysis of variance with Dunnett's multiple comparison test, ${ }^{* * *} p<0.001$ vs. control. $(\mathrm{D}+\mathrm{H})$ Representative images of the migrated and stained cells after $3 \mathrm{~h}$ of stimulation. 


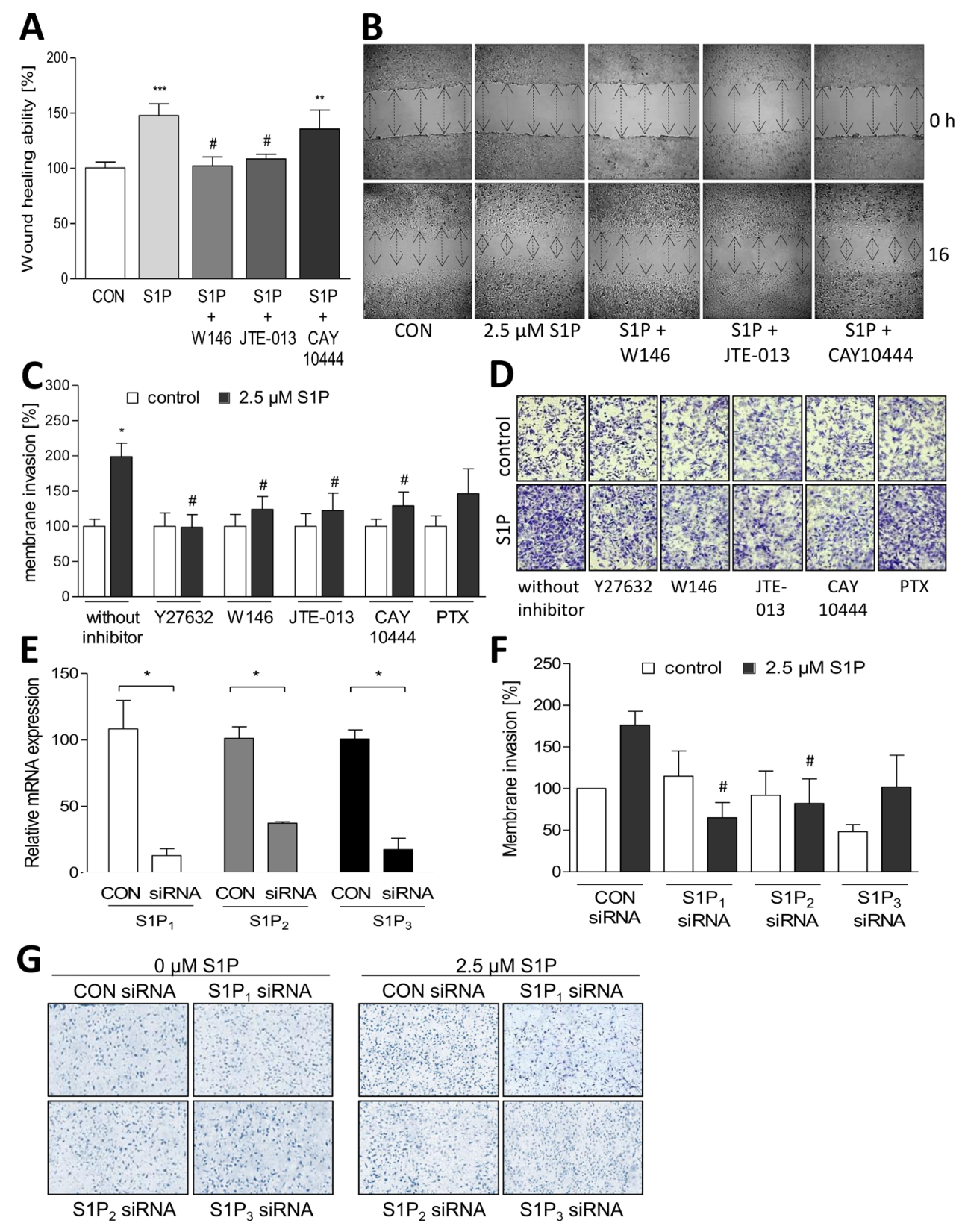

Figure 5: Association between S1P receptors and migration of LN18 GBM cells. (A + B) Analysis of LN18 cell migration using the wound closure assay with setting a scratch into the cell layer and measurement of the wound width at the beginning of the experiment $(0 \mathrm{~h})$ and $16 \mathrm{~h}$ after treatment with $\mathrm{MeOH}$ (control), S1P alone $(2.5 \mu \mathrm{M}), \mathrm{S} 1 \mathrm{P}+10 \mu \mathrm{M} \mathrm{W} 146, \mathrm{~S} 1 \mathrm{P}+10 \mu \mathrm{M} \mathrm{JTE}-013$ or S1P + $10 \mu \mathrm{M}$ CAY10444. Cells were pre-treated for $1.5 \mathrm{~h}$ with W146, JTE-013, CAY10444 or DMSO (as solvent for the inhibitors) before adding S1P. (A) Wound closure ability is shown in relation to the control (100\%), mean values and SD, $n=3$, One-way analysis of variance with Dunnett's multiple comparison test, ${ }^{* * *} p<0.001$ vs. control, $\# p<0.05$ vs. S1P alone. (B) Representative images of the wound width at 0 and $16 \mathrm{~h}$, the wound width is marked by arrows. $(\mathbf{C}+\mathbf{D})$ Analysis of LN18 cell migration using the Boyden chamber assay after inhibition of S1P 1 with W146 $(10 \mu \mathrm{M}), \mathrm{S}_{1} \mathrm{P}_{2}$ with JTE-013 $(10 \mu \mathrm{M}), \mathrm{S}_{1} \mathrm{P}_{3}$ with CAY10444 $(10 \mu \mathrm{M})$, p160ROCK with Y27632 $(10 \mu \mathrm{M})$ or $\mathrm{G}_{\mathrm{i} / \mathrm{o}}$ signaling with Pertussis Toxin (PTX, $200 \mathrm{ng} / \mathrm{ml})$. Cells were treated for $3 \mathrm{~h}$ with S1P $(2.5 \mu \mathrm{M})$ with or without the indicated inhibitors, fixed on the lower side of the membrane, stained with crystal violet and counted. (C) Counted cells are shown in relation to the respective control (without inhibitor, $100 \%$ ), mean values and SD, $n=3, * p<0.05$ vs. control, $\# p<0.05$ vs. S1P alone. (D) Representative images of the migrated and stained cells after $3 \mathrm{~h}$ of stimulation. (E) Relative gene expression of $\mathrm{S}_{1} \mathrm{P}_{1}, \mathrm{~S}_{1} \mathrm{P}_{2}$ and $\mathrm{S}_{\mathrm{P}}$ after siRNA mediated silencing of the respective $\mathrm{S} 1 \mathrm{P}$ receptor subtype in LN18 GBM cells $48 \mathrm{~h}$ after transfection in comparison to control siRNA. mRNA expression levels were analyzed by quantitative RT-PCR with normalization to $18 \mathrm{~S}$ rRNA and shown as mean values and SD, $n=3$, Mann Whitney $U$ test, ${ }^{*} p<0.05$ vs. control siRNA $(\mathrm{CON})$. $(\mathbf{F}+\mathbf{G})$ Analysis of LN18 cell migration using the Boyden chamber assay after siRNA mediated silencing of $\mathrm{S}_{1} \mathrm{P}_{1}, \mathrm{~S}_{1} \mathrm{P}_{2}$ or $\mathrm{S}_{1} \mathrm{P}_{3}$ in comparison to control transfected cells. After $3 \mathrm{~h}$ of stimulation with $\mathrm{S} 1 \mathrm{P}(2.5 \mu \mathrm{M})$, cells were fixed on the lower side of the membrane, stained with crystal violet and counted. (F) Counted cells are shown in relation to the control (100\%), mean values and $\mathrm{SD}, n=3$, One-way analysis of variance with Dunnett's multiple comparison test, ${ }^{*} p<0.05$ vs. control. (G) Representative images of the migrated and stained cells after $3 \mathrm{~h}$ of stimulation. 
by specific inhibitors such as PD98059 (MEK/ERK inhibitor), SB202190 (p38 inhibitor), WP1066 (STAT3 inhibitor) and LY294002 (PI3K/AKT1 inhibitor). As seen in Figure $6 \mathrm{~A}$ and $6 \mathrm{~B}$, only inhibition of the PI3K/AKT signaling by LY294002 almost completely abolished the S1P-mediated increase in LN18 cell migration from 208\% (2.5 $\mu \mathrm{M}$ S1P alone) to $106 \%$. The p38 inhibitor SB202190 also diminished the cell migration of LN18 cells to $158 \%$ but this effect was not statistically significant.

Immunoblot analyses showed a significant 4-fold increase in the phosphorylation status for both AKT1 (pAKT1) and ERK1/2 (pERK1/2) 5 and $10 \mathrm{~min}$ after stimulation of LN18 cells with $2.5 \mu \mathrm{M}$ S1P (Figure 6C and $6 \mathrm{~F}$ ). In contrast, phosphorylation of p38 and STAT3 showed no alterations after treatment of LN1 8 cells with S1P (Figure 6D and 6E).

\section{DISCUSSION}

Despite an aggressive multimodal therapy, the prognosis of patients with glioblastoma multiforme (GBM) is very poor with a 5-year survival rate of below $5 \%$ and a median patient life span of 12 to 15 month from diagnosis $[1,2]$. The examination of signaling pathways which are responsible for the rapid recurrence are strongly necessary and might contribute to the optimization of the current therapeutic intervention.

The bioactive lipid S1P has been implicated in various disorders such as cancer and inflammatory diseases. Recent studies argue for a potential role of S1P signaling in GBM growth and progress but the available data concerning the impact of the S1P signaling system in GBM cell proliferation and migration partly differ in their conclusions [22-27].

The purpose of this study was to investigate the role of $\mathrm{S} 1 \mathrm{P}$ receptors and $\mathrm{S} 1 \mathrm{P}$ metabolizing enzymes for the prognosis of GBM patients as well as for proliferation and migration of GBM cells in vitro. Our data indicate that expression of $\mathrm{S} 1 \mathrm{P}$ receptors $\mathrm{S}_{1} \mathrm{P}_{1}, \mathrm{~S}_{1} \mathrm{P}_{2}$ and $\mathrm{S}_{1} \mathrm{P}_{3}$ as well as of SphK1 is up-regulated in GBM tissue in comparison to non-malignant brain whereas SphK2 was unchanged and a trend to a lower expression of $\mathrm{S} \mathrm{P}_{5}$ was observed in GBM. This is only partly in accordance with a recently published study which shows overexpression

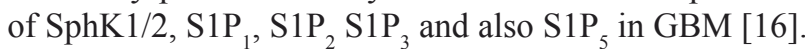
Conversely to the results of Quint and colleagues [16], another rather small study describes a down-regulation of $\mathrm{S}_{1} \mathrm{P}_{1}$ expression in GBM which correlates with a shorter survival of the patients [25]. These observations argue for certain variability in the expression of genes related to $\mathrm{S} 1 \mathrm{P}$ signaling in heterogeneous tumors such as GBM and also indicates the need for larger patient cohorts. Another recent study from Abuhusain et al. demonstrated that an altered $\mathrm{S} 1 \mathrm{P} /$ ceramide balance with reduced $\mathrm{C} 18$ ceramide and elevated S1P as well as increased SphK1 and decreased SGPP2 expression may be an important feature of human gliomas [17]. SGPP1 and SGPL were not examined in the study of Abuhusain and colleagues, therefore we additionally investigated the expression of these S1P degrading enzymes, however we found no significant alterations in GBM tissue and only a tendency of a reduced SGPP2 expression $(p=0.1917)$. To evaluate the role of the key players in S1P signaling in the prognosis of patients with GBM, Kaplan-Meier survival curves were calculated for patients divided in two subgroups depending on the median gene expression. These survival analyses showed a significant association between survival time and expression of $\mathrm{S}_{1} \mathrm{P}_{1}, \mathrm{~S}_{1} \mathrm{P}_{2}$ and SGPP1 but not of $\mathrm{S}_{1} \mathrm{P}_{5}$ for which an prognostic impact was described by Quint and colleagues [16]. In agreement with the study from Yoshida et al. [25], a high expression of $\mathrm{S}_{1} \mathrm{P}_{1}$ also correlated with a prolonged survival of GBM patients in our study. This was unexpected since S1P is known to stimulate tumor cell proliferation and migration through binding to $\mathrm{S}_{\mathrm{P}}$. Nevertheless, siRNA-mediated silencing of $\mathrm{S}_{1} \mathrm{P}_{1}$ in $\mathrm{T} 98 \mathrm{G}$ and $\mathrm{G} 112$ glioma cells resulted in promoted cell proliferation [25]. Furthermore forced

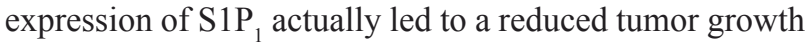
in transplanted gliomas in vivo [25]. Thus, it seems possible that, depending on the individual expression of $\mathrm{S}_{1} \mathrm{P}_{1}$ and the other $\mathrm{S} 1 \mathrm{P}$ receptor subtypes and in combination with differentially activated intracellular signaling pathways, S1P can mediate both pro- and anti-tumorigenic effects. Our results do not argue for an extraordinary role of $\mathrm{S}_{1} \mathrm{P}_{1}$ in proliferation of LN18 glioma cells since the $\mathrm{S}_{1} \mathrm{P}_{1}$ inhibitor W146 only slightly decreased cell viability whereas potent function of $\mathrm{S}_{1} \mathrm{P}_{1}$ in S1P-mediated tumor cell migration was observed. The same effect could be shown for inhibition of $\mathrm{S} \mathrm{P}_{2}$ by JTE-013. In agreement with the pro-migratory effect of $\mathrm{S}_{1} \mathrm{P}_{2}$ in our in vitro experiments, a high expression level of $\mathrm{S}_{1} \mathrm{P}_{2}$ correlated with a poor survival outcome. Thus, it is possible that signaling effects of $\mathrm{S}_{1} \mathrm{P}_{2}$ in vivo are more important for cell migration and tumor invasion than the $\mathrm{S}_{1} \mathrm{P}_{1}$ function.

Furthermore, our survival analyses showed that low expression of the phosphatase SGPP1 is associated with a prolonged survival rate of patients with GBM. SGPP1 dephosphorylates S1P back to sphingosine and thereby reduces the local S1P levels and its mediated effects [28]. Beside its role in proliferation, S1P regulates diverse cellular processes that are important for immune responses including differentiation, trafficking and migration of numerous types of immune cells such as $\mathrm{T}$ and B lymphocytes, natural killer cells, macrophages, or haematopoietic progenitors as well as cytokine and chemokine production [29]. The GBM tissue involves not only the tumor cells itself but rather represents a complex formation of extracellular matrix and diverse non-malignant cells such as endothelial cells, microglia or immunocompetent cells from peripheral blood [30]. So it might be possible that the locally produced S1P attracts 

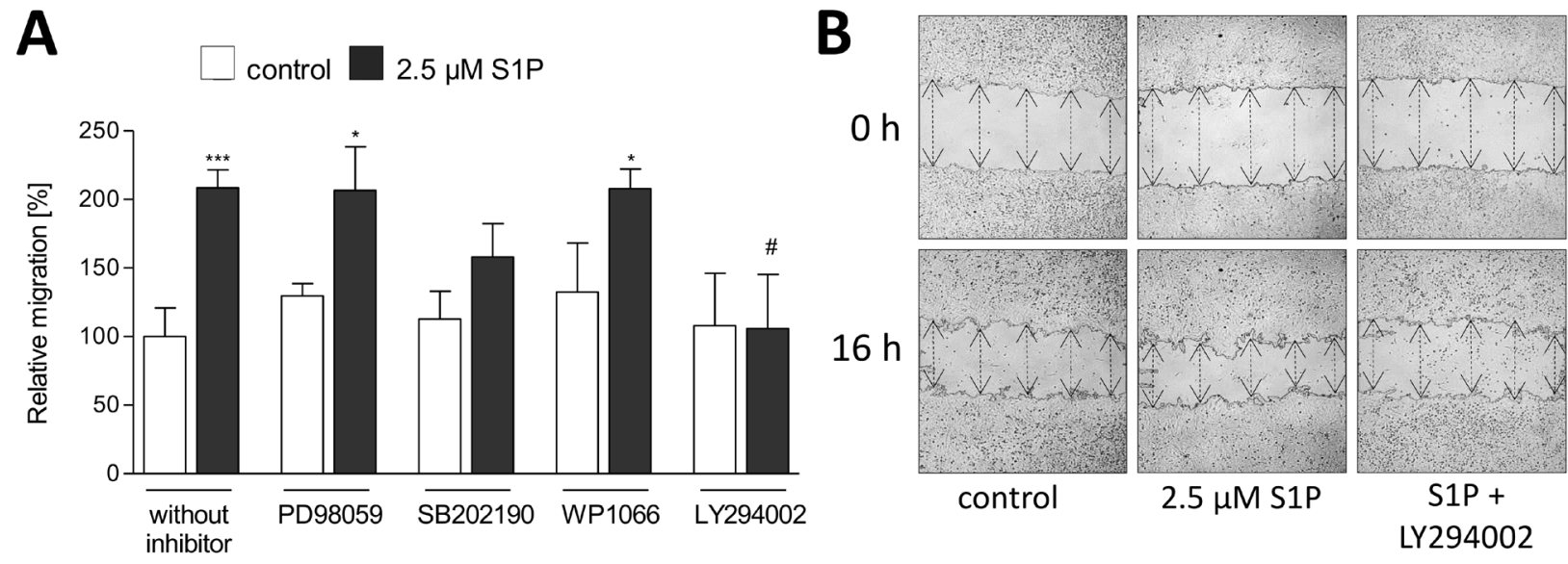

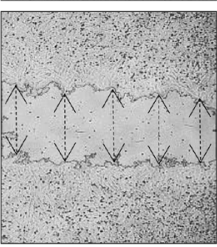

control

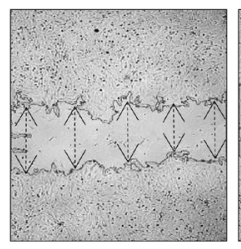

$2.5 \mu \mathrm{M}$ S1P

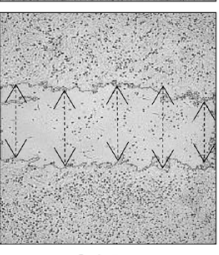

$\mathrm{S} 1 \mathrm{P}+$

LY294002
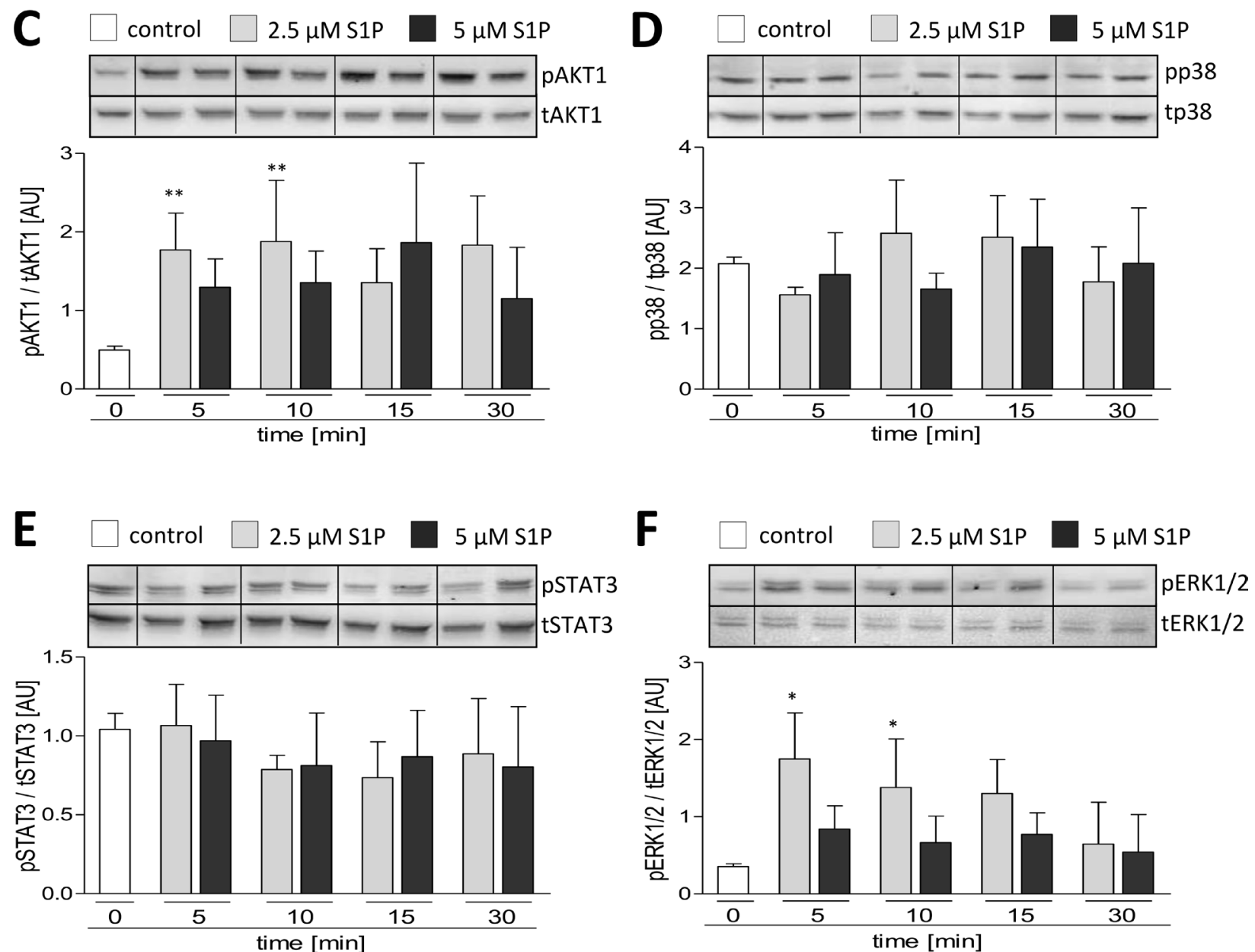

Figure 6: Association between signaling pathways and S1P induced migration of LN18 GBM cells. (A + B) Analysis of LN18 cell migration using the wound closure assay with setting a scratch into the cell layer and measurement of the wound width at the beginning of the experiment $(0 \mathrm{~h})$ and $16 \mathrm{~h}$ after treatment with DMSO (solvent), $10 \mu \mathrm{M}$ PD98059, $10 \mu \mathrm{M}$ SB202190, $10 \mu \mathrm{M}$ WP1066 or $10 \mu \mathrm{M}$ LY294002 either in combination with $\mathrm{MeOH}$ (control) or $2.5 \mu \mathrm{M}$ S1P. Cells were pre-treated for $1.5 \mathrm{~h}$ with PD98059, SB202190, WP1066, LY294002 or DMSO before adding S1P. (A) Wound closure ability is shown in relation to the control (100\%), mean values and $\mathrm{SD}, n=3$, One-way analysis of variance with Dunnett's multiple comparison test, ${ }^{*} p<0.05$ and $* * * p<0.001$ vs. control, \#p<0.05 vs. S1P alone. (B) Representative images of the wound width at 0 and $16 \mathrm{~h}$, the wound width is marked by arrows. (C-F) Immunoblot analysis of the phosphorylated (p) and total (t) signaling molecules AKT1 (C), p38 (D), STAT3 (E) and ERK1/2 (F). LN18 GBM cells were treated with 2.5 or $5 \mu \mathrm{M} \mathrm{S1P}$ for 5, 10, 15 and $30 \mathrm{~min}$. Representative blots of four independent experiments each. Densitometric analyses of four independent experiments, phosphorylated protein level (p) was normalized to the total protein level ( $\mathrm{t})$, mean values and SD. ${ }^{*} p<0.05$ and $* * p<0.005$ vs. control. 
immune cells into the tumor region to attack the malignant cells being enhanced by a low expression of SGPP1 and thus higher S1P levels.

Glioma cell lines are able to produce and release $\mathrm{S} 1 \mathrm{P}$, express $\mathrm{S} 1 \mathrm{P}$ receptors and also respond to this signaling molecule $[18,19,23]$. The LN18 GBM cells used in our study express $\mathrm{S}_{1} \mathrm{P}_{1}, \mathrm{~S}_{2} \mathrm{P}_{2}, \mathrm{~S}_{1} \mathrm{P}_{3}$ and $\mathrm{S}_{1} \mathrm{P}_{5}$ as well as $\mathrm{SphK}$ and therefore can be assumed as a suitable model for the investigation of S1P-mediated effects in GBM cells. Stimulation of cultured GBM cells with S1P either results in unchanged or enhanced cell proliferation $[23,24]$ mediated by $\mathrm{S}_{1} \mathrm{P}_{1}, \mathrm{~S}_{1} \mathrm{P}_{2}$ and $\mathrm{S}_{1} \mathrm{P}_{3}$ whereas $\mathrm{S}_{1} \mathrm{P}_{5}$ inhibits $\mathrm{S} 1 \mathrm{P}$-stimulated cell proliferation [24]. In our study, S1P did not directly stimulate LN18 cell viability. Since LN18 cells express high levels of $\mathrm{S}_{1} \mathrm{P}_{5}$, for which a role in survival of GBM patients has been suggested [16], and to a minor extent expresses $\mathrm{S}_{1} \mathrm{P}_{1}$ and $\mathrm{S}_{1} \mathrm{P}_{2}$, proliferative effects of $\mathrm{S} 1 \mathrm{P}$ via $\mathrm{S} 1 \mathrm{P}_{1-3}$ could be counteracted by $\mathrm{S}_{\mathrm{P}}$. As described above, blockade of S1P by W146 and S1P $\mathrm{P}_{2}$ by JTE-013 only marginally impaired the viability of LN18 cells at a concentration of $10 \mu \mathrm{M}$ whereas the $\mathrm{S}_{3} \mathrm{P}_{3}$ inhibitor CAY10444 had no influence. In contrast, inhibition of SphK with SKIII significantly impaired viability of LN18 cells. This is in agreement with the recently described suppression of GBM growth by inhibition of SphK1 in an animal model [31]. In addition, cytotoxic effects of SphK inhibitors were also seen in Temozolomide-resistant glioma cells in vitro [32]. A recent study by Van Brocklyn et al. demonstrated in Kaplan-Meier survival analysis that expression of SphK1 is associated with the outcome of GBM patients [33] but such a relation between patient's survival and SphK1 expression was not detectable in our patient cohort despite an elevated expression of SphK1 in the investigated GBM specimens. The observed upregulation of SphK1 is, however, in accordance with data from Yoshida and colleagues and this group also found no significant correlation of SphK expression with the histological grade or with patient survival.

Inhibition of SphK (by SKI-II), S1P (by W146),

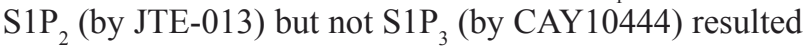
in an enhanced migration of LN18 cells in our in vitro studies. Therefore one would expect that high expression of $\mathrm{S}_{1} \mathrm{P}_{1}$ and $\mathrm{S}_{1} \mathrm{P}_{2}$ in GBM specimens is associated with a poor prognosis. But as mentioned above this was only the case for $\mathrm{S}_{1} \mathrm{P}_{2}$ but not for $\mathrm{S}_{1} \mathrm{P}_{1}$. It has been shown before that motility of GBM cells is stimulated by S1P [26] and involves both $\mathrm{S}_{1} \mathrm{P}_{1}$ and $\mathrm{S}_{1} \mathrm{P}_{3}$. In contrast, $\mathrm{S}_{1} \mathrm{P}_{2}$ has been suggested to inhibit migration and motility [23, 27]. Interestingly, Young and Van Brocklyn demonstrated an opposite effect for the $\mathrm{S}_{1} \mathrm{P}_{2}$ receptor, actually enhancing invasion of GBM cells as also seen for $\mathrm{S}_{1} \mathrm{P}_{1}$ and $\mathrm{S}_{1} \mathrm{P}_{3}$ [24]. Our in vitro data using LN18 cells argue for a role of $\mathrm{S}_{1} \mathrm{P}_{1}$ and $\mathrm{S}_{1} \mathrm{P}_{2}$ but not of $\mathrm{S}_{1} \mathrm{P}_{3}$ in migration of GBM cells. W146 is described as a specific $\mathrm{S}_{1} \mathrm{P}_{1}$ antagonist at the concentrations used in our study $[34,35]$. In contrast, the $\mathrm{S} 1 \mathrm{P}_{2}$ inhibitor JTE-013 was shown to additionally antagonize $\mathrm{S}_{4}$, which was not expressed in GBM cells in our study, however additional off-target effects of JTE-013 cannot be excluded [36]. Furthermore, for the $\mathrm{S}_{1} \mathrm{P}_{3}$ inhibitor CAY 10444 blocking of purinergic P2 receptor and $\alpha_{\mathrm{A} 1}$ adrenoceptor was shown [36]. Therefore, the results obtained with the S1P receptor inhibitors were validated by siRNA mediated down-regulation of $\mathrm{S}_{1} \mathrm{P}_{1}$,

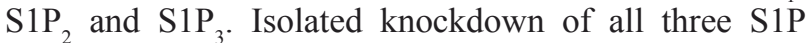
receptors resulted in a reduced migration of LN18 GBM cells whereby suppression of $\mathrm{S}_{1} \mathrm{P}_{1}$ had the strongest effect, which is in accordance with the pharmacological inhibition by $\mathrm{W} 146$, followed by $\mathrm{S}_{2} \mathrm{P}_{2}$ silencing. In contrast to the pharmacological inhibition of $\mathrm{S}_{3} \mathrm{P}_{3}$ using CAY10444, siRNA-mediated silencing of this receptor subtype also resulted in a trend to a reduced migration of LN18 cells.

To further analyze which pathway is involved in S1P-stimulated migration of LN18 cells, various inhibitors of signaling pathways, known to be activated by S1P, were utilized. Only inhibition of PI3-kinase/ AKT1 signaling by LY294002 completely inhibited S1P stimulated LN18 cell migration. This was confirmed by an increased phosphorylation of AKT1 after stimulation of the cells with S1P. The PI3-kinase/AKT1 pathway is known to be activated by $\mathrm{S}_{1} \mathrm{P}_{1}, \mathrm{~S}_{1} \mathrm{P}_{2}$ and $\mathrm{S} 1 \mathrm{P}_{3}$ via $\mathrm{G}_{\mathrm{i}}$ coupling of these receptors [27]. For $\mathrm{S}_{1} \mathrm{P}_{1}$ and $\mathrm{S}_{1} \mathrm{P}_{3}$ a PI3kinase/AKT1-dependent stimulation of cell migration is described whereas $\mathrm{S}_{3} \mathrm{P}_{3}$ uses this signaling cascade only as a side trail while Rho signaling as the main pathway may negatively regulate cell migration [27]. Nevertheless in our experiments, inhibition or specific silencing of $\mathrm{S}_{2} \mathrm{P}_{2}$ resulted in a significant reduction of migration of LN18 GBM cells. In accordance with this, glioma cell invasion was also increased by stimulation of $\mathrm{S}_{1} \mathrm{P}_{2}$ in a study by Young and Van Brocklyn [24].

In contrast to AKT1, STAT3 phosphorylation was not significantly changed after stimulation of LN18 cells with S1P despite a previously reported down-regulation of phosphorylated STAT3 in brain tumor stem cells after stimulation with the S1P analogue fingolimod [22]. For ERK1/2 we also found an increased phosphorylation after stimulation of LN18 cells with S1P but inhibition of this signaling cascade with PD98059 failed to reduce cell migration. Activation of ERK1/2 by S1P is known to increase growth and survival of GBM cells $[13,23]$ which was not observed in our GBM cell model. For inhibition of p38 kinase using SB202190, a tendency of a reduced LN18 cell migration was seen but the phosphorylation of p38 kinase was not increased after stimulation of the cells with S1P. Overall, our in vitro data argue for a significant role of the PI3-kinase/AKT1 pathway in S1Pmediated stimulation of GBM cell migration. This is in agreement with a recently published study showing that the sphingosine analogue FTY720 (fingolimod) reduces migration and invasion of GBM cells by blocking the PI3-kinase/AKT signaling axis [37]. 
In summary, our data argue for a participation of S1P signaling in proliferation and migration of GBM cells. Individual components of the S1P pathway represent prognostic factors for survival of patients with GBM. Additionally, our results implicate a very complex interplay between S1P receptors, S1P signaling and other tumor-promoting signaling cascades in GBM making it difficult to directly link in vivo to in vitro data. Perspectively, the selective inhibition of S1P receptor subtypes could represent a therapeutic approach for GBM patients and requires further evaluation.

\section{MATERIALS AND METHODS}

\section{Patients samples}

Following an institutional review board-approved protocol, fresh human GBM tissues were collected from 117 patients (70 males, 47 females) who underwent surgical removal of GBM within their therapeutic regime (study period from 15.10.2007 to 31.07.2014). The histological analyses are based on the World Health Organization criteria [38]. Tumor specimens were obtained from primary tumors $(n=77)$ and relapses $(n=40)$. The last update of the vital status was on July 31, 2014, delivering 67 full cases of deceased patients with primary tumor for subsequent survival analysis. Overall survival was measured from the date of diagnosis to the date of death. Table 1 shows the detailed clinical characteristics. Beside GBM samples, eight non-neoplastic brain tissues (frontal/temporal lobes) from the Institute of Pathology/Department of Neuropathology of the University Greifswald were analyzed. Brain tissues of these control cases were obtained by routine autopsy. After the brain was removed tissue samples were cut and frozen at minus $80^{\circ} \mathrm{C}$ immediately. The autopsy cases died of pneumonia, heart failure, sepsis or carcinoma of pancreas, respectively. There were no neurological disorders. Further, RNA samples of two non-malignant (one frontal and one temporal lobe) specimens were obtained from BioChain Institute Inc. (Newark, CA, USA).

\section{Cell culture}

For in vitro experiments we used the LN18 GBM cell line which was obtained from the American Type Culture Collection (ATCC, Manassas, VA, USA). LN18 cells were maintained in DMEM supplemented with $10 \%$ FCS, $2 \mathrm{mM}$ glutamine and $2 \mathrm{mM}$ non-essential amino acids at $37^{\circ} \mathrm{C}, 95 \%$ humidity and $5 \% \mathrm{CO}_{2}$. All cell culture materials were from PAA Laboratories (Cölbe, Germany). For stimulation experiments with $\mathrm{S} 1 \mathrm{P}$ and inhibitors, LN18 cells were cultured in DMEM containing 0.05\% FCS since. Reagents for cell culture experiments were as follows: S1P, JTE-013, W146, (all Sigma-Aldrich, Deisenhofen, Germany), LY294002, PD98059, SB202190,
WP1066, Y27632 (all Calbiochem, Bad Soden, Germany), CAY10444 (CAYMAN Chemicals, Michigan, USA) and Pertussis Toxin (Tocris Biosciences, Bristol, UK).

\section{Isolation of tumor cells from glioblastoma samples}

Isolation of single-cell suspension from human glioblastoma samples was performed using the Brain Tumor Dissociation Kit (Miltenyi Biotech, Bergisch Gladbach, Germany) according to the manufacturer's protocol. Afterwards, the isolated tumor cells were cultured as adherent cells in DMEM supplemented with $10 \%$ FCS, $2 \mathrm{mM}$ glutamine and $2 \mathrm{mM}$ non-essential amino acids at $37^{\circ} \mathrm{C}, 95 \%$ humidity and $5 \% \mathrm{CO}_{2}$. After the second passage, RNA or protein was isolated and expression of $\mathrm{S} 1 \mathrm{P}_{1-5}, \mathrm{SphK} 1$ and 2, SGPP1 and 2 and SGPL1 was analyzed by quantitative RT-PCR or Western Blot in comparison to the human glioblastoma cell lines LN18 and U87MG.

\section{Quantitative real-time PCR analysis}

For mRNA expression analysis, total RNA was isolated using PeqGold RNAPure (PeqLab, Erlangen, Germany) and reversely transcribed using the High Capacity cDNA Reverse Transcription Kit (Applied Biosystems by Life Technologies, Weiterstadt, Germany). The expression was analyzed by the following Gene Expression Assays on Demand from Applied Biosystems: $\mathrm{S} 1 \mathrm{P}_{1}$, Hs00173499_m1; S1P ${ }_{2}, \mathrm{Hs} 01015603$ s1; S1P, Hs01019574_m1; $\bar{S}_{1} \mathrm{P}_{4}, \mathrm{Hs} 02330084$ s1; S1P, Hs009 24881_m1; SphK1, Hs00184211_m1; SphK2, Hs002199 99_m1; SGPP1, Hs00229266_m1; SGPP2, Hs0054 4786_m1; SGPL1, Hs00393705_m1, and eukaryotic 18S rRNA endogenous control, 4310893E. Quantitative realtime PCR was performed in a 7900 HT Fast Real-Time PCR system from Applied Biosystems. Each mRNA level was normalized to $18 \mathrm{~S}$ rRNA and analyzed by the $\Delta \Delta \mathrm{ct}$ method.

\section{Immunofluorescence microscopy}

LN18 cells were seeded onto cover slips at a density of 50000 cells/well in a 12-well multiplate in $1 \mathrm{ml}$ culture medium for $24 \mathrm{~h}$. After aspiration of the medium and three washing steps with PBS, cells were fixed in $4 \%$ paraformaldehyde for $10 \mathrm{~min}$, rinsed with PBS three times and then permeabilized with $0.1 \%$ Triton X-100 for 10 min. Afterwards, cells were blocked in 5\% FCS for $1 \mathrm{~h}$, and the primary antibody against SphK1 (Abgent, Hamburg, Germany) was incubated at $4^{\circ} \mathrm{C}$ overnight in blocking solution at a dilution of 1:50. Following three washing steps with PBS for each 5 minutes, cells were incubated for 2 hours with the secondary Alexa Fluor 488 labeled goat anti-mouse antibody (life technologies, 
Table 1: Clinico-pathological characteristics of tumor specimens

\begin{tabular}{|c|c|}
\hline Characteristic & value \\
\hline $\mathrm{N}$ (primary tumor; relapse) & $117(77 ; 40)$ \\
\hline median age at diagnose (25th-percentile; 75 th-percentile) & $64(54 ; 71)$ \\
\hline \multicolumn{2}{|l|}{ age classes } \\
\hline$<50$ years & $15(12.8 \%)$ \\
\hline $50-<60$ years & $35(29.9 \%)$ \\
\hline $60-<70$ years & $29(24.8 \%)$ \\
\hline $70-<80$ years & $29(24.8 \%)$ \\
\hline$>80$ years & $9(7.7 \%)$ \\
\hline \multicolumn{2}{|l|}{ Gender } \\
\hline male & $70(60.9 \%)$ \\
\hline female & $47(40.9 \%)$ \\
\hline male-to-female ratio & 1.5 \\
\hline \multicolumn{2}{|l|}{ vital status at study end } \\
\hline dead & $67(58.3 \%)$ \\
\hline alive & $50(43.5 \%)$ \\
\hline \multicolumn{2}{|l|}{ resection grade } \\
\hline total & $57(49.6 \%)$ \\
\hline subtotal & $60(52.2 \%)$ \\
\hline \multicolumn{2}{|l|}{ therapy regimen ${ }^{\mathrm{a}}$} \\
\hline radiotherapy and chemotherapy & $48(41.0 \%)$ \\
\hline only radiotherapy & $15(12.8 \%)$ \\
\hline only temozolomide & $8(6.8 \%)$ \\
\hline other regimen & $11(9.4 \%)$ \\
\hline no adjuvant therapy & $10(8.5 \%)$ \\
\hline
\end{tabular}

$\mathrm{a}=25$ therapy regimens could not be accessed.

Darmstadt, Germany) at a dilution of 1:200. After three further washing steps with PBS for 5 minutes, cells were incubated for $10 \mathrm{~min}$ with DAPI $\left(4^{\prime}, 6^{\prime}\right.$-diamidino-2phenylindole, diluted 1:1000 in PBS, life technologies, Darmstadt, Germany) for counterstaining of nuclei followed by washing with PBS for three times $(5 \mathrm{~min}$ each). Finally, cells were embedded in Dako Fluorescence Mounting Medium (Dako North West Inc., Carpintera, USA) on a slide and dried flat overnight before being examined at the Zeiss LSM780 fluorescence microscope (Carl Zeiss Microscopy, Jena, Germany).

\section{Western blot analysis}

Protein lysates from cultured cells were prepared by using the following lysis buffer: $50 \mathrm{mM}$ Tris-HCl pH 7.4, $100 \mathrm{mM} \mathrm{NaCl}, 0.1 \%$ Triton X-100, 5 mM EDTA containing protease/phosphatase inhibitors $(1 \mathrm{mM}$ phenylmethylsulfonyl fluoride, $1 \mathrm{mM}$ leupeptin, $1 \mathrm{mM}$ aprotinin, and $250 \mu \mathrm{g} / \mathrm{mL}$ sodium vanadate). Briefly, after centrifugation of cells at $6000 \mathrm{rpm}$ the resulting pellet was dissolved in the lysis buffer and incubated on ice for 45 min. The BCA Protein Assay Kit (Thermo Fisher Scientific) was used for the protein quantification. Subsequently, after denaturation in Laemmli buffer at $95^{\circ} \mathrm{C}$ for $5 \mathrm{~min}, 25 \mu \mathrm{g}$ of each sample was separated on a $10 \%$ sodium dodecyl sulfate polyacrylamide gel. Whatman nitrocellulose membranes (Proton, Schleicher and Schuell, Dassel, Germany) were used for immunoblotting in a tank blot system (Biometra, Göttingen, Germany). The membrane was blocked in 5\% skim milk in Tris-buffered saline containing $0.05 \%$ Tween 20 (TBST) for $1 \mathrm{~h}$ at room temperature. The following primary antibodies were diluted in TBST and $0.05 \%$ sodium azide and incubated either for $2 \mathrm{~h}$ at room temperature or overnight at $4^{\circ} \mathrm{C}$ : monoclonal rabbit anti-phosphorylated Akt1 (Ser473), monoclonal rabbit anti-Akt1, monoclonal rabbit antiphosphorylated ERK1/2 (T201/Y204), monoclonal mouse anti-ERK1/2, monoclonal rabbit anti-phosphorylated p38 (T180/Y182), rabbit anti-p38, monoclonal mouse antiphosphorylated STAT3 (Y705), monoclonal mouse antiSTAT3 (all from Cell Signaling Technology, Boston, 
USA). The secondary horseradish peroxidase conjugated goat anti-rabbit or goat anti-mouse $\operatorname{IgG}$ antibodies (Bio-Rad, Munich, Germany) were used at a 1:2000 dilution for $1.5 \mathrm{~h}$ at room temperature. The detection of chemiluminescence signals was carried out with the ChemiDoc XRS Imaging System (Bio-Rad, Munich, Germany) using ECL Plus Western Blotting Substrate (Amersham Biosciences, Freiburg, Germany) followed by densitometric analysis (Quantity One, Bio-Rad). The relative optical densities of the specific phosphorylated bands were calculated and normalized to the respective total kinase expression.

\section{siRNA mediated silencing of human $\mathrm{S1P}_{1}, \mathrm{S1P}_{2}$ and $\mathrm{S}_{3} \mathrm{P}_{3}$}

LN18 cells were transfected using the Lipofectamine ${ }^{\circledR} 2000$ reagent protocol (Invitrogen). Gene specific siRNA and control siRNA (both OriGene Technologies, USA) were used at a final concentration of 5 pmol. To optimize the knockdown effectivity the whole transfection procedure was repeated $24 \mathrm{~h}$ after the first application of the siRNA. RNA knockdown was tested $48 \mathrm{~h}$ post-transfection using quantitative real-time PCR.

\section{Cell viability analysis}

LN18 cells were seeded at a density of 10000 cells/ well onto 96-well multiplates. 24 hours later, the medium was changed and cells were incubated for different time points with fresh medium containing S1P or the respective $\mathrm{S} 1 \mathrm{P}$ receptor inhibitor. Afterwards, medium was removed and replaced by fresh medium containing $10 \%$ resazurine (PromoCell, Heidelberg, Germany), and cells were further incubated for $2 \mathrm{~h}$ at $37^{\circ} \mathrm{C}$. Fluorescence signals were recorded using a multiplate reader (Tecan Infinite M200, Crailsheim, Germany, excitation, $530 \mathrm{~nm}$; emission, $590 \mathrm{~nm}$ ) and data were calculated as percentage of cell viability of solvent (MeOH for S1P, DMSO for inhibitors) treated cells.

\section{Scratch wound healing assay}

For the wound healing assay, 150000 cells/ well were seeded onto 24-well multiplates. When cells reached confluency, a defined wound scratch was set into the middle of the cell layer using a yellow pipet tip. Detached cells were removed by washing with PBS followed by application of $5 \mathrm{mM}$ hydroxy urea as proliferation inhibitor. Using the PALM Robo Software of the AxioVision HXP120C microscope (Carl Zeiss Microscopy, Jena, Germany) the wound was imaged and the exact position of the image was saved to analyze the same region after the respective incubation time. After the pre-incubation with hydroxy urea for $1 \mathrm{~h}$, cells were treated with the different inhibitors and/or S1P for $16 \mathrm{~h}$ followed by the analysis of the wound width (Software AxioVision SE64 Rel. 4.9, Carl Zeiss Microscopy).

\section{Boyden chamber assay}

Using a Boyden chamber (Neuro Probe Standard Chemotaxis Chamber, Neuro Probe Inc., Gaithersburg, USA) we performed a transwell migration assay. Briefly, cells were cultured for $24 \mathrm{~h}$ in serum-free media followed by trypsinization and seeding of 5000 cells/50 $\mu 1$ FCSfree media into the upper well of the Boyden chamber. A polycarbonate membrane with a pore size of $8 \mu \mathrm{m}$ (Whatman GmbH, Dassel, Germany) was located between the upper and the bottom chamber. Cells were treated for $3 \mathrm{~h}$ with the respective inhibitor and/or S1P. Afterwards, migrated cells were fixed on the lower side of the membrane with $4 \%$ paraformaldehyde, stained with crystal violet solution for $30 \mathrm{~min}$ and counted using the cell counting tool of ImageJ (National Institute of Health, Maryland, USA).

\section{Statistical analysis}

Statistical analyses were performed with GraphPad Prism 5.0. (GraphPad Software, Inc., California, USA). Data of in vitro analyses represent 3 or 4 independent experiments (indicated in the figure legends and shown as mean $\pm \mathrm{SD}$ ). Box plots of data of patients' samples are shown as the median and the 5th and 95th percentiles. Pairwise comparisons were performed using MannWhitney $U$ test. More than 2 groups were compared by OneWay ANOVA and Dunnett's multiple comparison test. The duration of a patient's overall survival (OS) was defined as the time from the first tumor detection until death. Information on vital status and date of death were obtained from official population registry. Based on the gene expression, GBM specimens were divided into the lower half versus the upper half of gene expression level as determined by real-time PCR $(<$ Median vs. $>$ $=$ Median expression). These were used for calculation of Hazard Ratios $(<$ Median vs. $>=$ Median expression $)$ and creation of Kaplan-Meier graphs which were compared by log-rank (Mantel-Cox) test. Specimens with expression rates lower than the detection limit of quantitative realtime PCR were excluded from data analysis. Statistical significances were defined as ${ }^{*} p<0.05,{ }^{*} p<0.01$, and $* * * p<0.001$.

\section{Authors' contributions}

SBM, AB, HWSS, WH and BHR participated in research design. $\mathrm{SBM}, \mathrm{SL}, \mathrm{TH}, \mathrm{AB}, \mathrm{JK}, \mathrm{SH}$, and $\mathrm{SV}$ conducted experiments. SBM, SL, TH, AB, HP, CH, KW and SM performed data analysis. SBM, HP and BHR wrote or contributed to the writing of the manuscript. All authors read and approved the final manuscript. 


\section{CONFLICTS OF INTEREST}

None.

\section{REFERENCES}

1. Stupp R, Mason WP, van den Bent MJ, Weller M, Fisher B, Taphoorn MJ, Belanger K, Brandes AA, Marosi C, Bogdahn U, Curschmann J, Janzer RC, Ludwin SK, et al. Radiotherapy plus concomitant and adjuvant temozolomide for glioblastoma. N Engl J Med. 2005; 352:987-996.

2. Anton K, Baehring JM, Mayer T. Glioblastoma multiforme: overview of current treatment and future perspectives. Hematol Oncol Clin North Am. 2012; 26:825-853.

3. Alves TR, Lima FR, Kahn SA, Lobo D, Dubois LG, Soletti R, Borges H, Neto VM. Glioblastoma cells: a heterogeneous and fatal tumor interacting with the parenchyma. Life Sci. 2011; 89:532-539.

4. Strub GM, Maceyka M, Hait NC, Milstien S, Spiegel S. Extracellular and intracellular actions of sphingosine-1phosphate. Adv Exp Med Biol. 2010; 688:141-155.

5. Liu H, Chakravarty D, Maceyka M, Milstien S, Spiegel S. Sphingosine kinases: a novel family of lipid kinases. Prog Nucleic Acid Res Mol Biol. 2002; 71:493-511.

6. Saba JD, Hla T. Point-counterpoint of sphingosine 1-phosphate metabolism. Circ Res. 2004; 94:724-734.

7. Serra M, Saba JD. Sphingosine 1-phosphate lyase, a key regulator of sphingosine 1-phosphate signaling and function. Adv Enzyme Regul. 2010; 50:349-362.

8. Anelli V, Bassi R, Tettamanti G, Viani P, Riboni L. Extracellular release of newly synthesized sphingosine1-phosphate by cerebellar granule cells and astrocytes. J Neurochem. 2005; 92:1204-1215.

9. Bassi R, Anelli V, Giussani P, Tettamanti G, Viani P, Riboni L. Sphingosine-1-phosphate is released by cerebellar astrocytes in response to bFGF and induces astrocyte proliferation through Gi-protein-coupled receptors. Glia. 2006; 53:621-630.

10. Rosen H, Goetzl EJ: Sphingosine 1-phosphate and its receptors. an autocrine and paracrine network. Nat Rev Immunol. 2005; 5:560-570.

11. Maceyka M, Payne SG, Milstien S, Spiegel S. Sphingosine kinase, sphingosine-1-phosphate, and apoptosis. Biochim Biophys Acta. 2002; 1585:193-201.

12. Hla T. Physiological and pathological actions of sphingosine 1-phosphate. Semin Cell Dev Biol. 2004; 15:513-520.

13. Leong WI, Saba JD. S1P metabolism in cancer and other pathological conditions. Biochimie. 2010; 92:716-723.

14. Xia P, Gamble JR, Wang L, Pitson SM, Moretti PA, Wattenberg BW, D'Andrea RJ, Vadas MA. An oncogenic role of sphingosine kinase. Curr Biol. 2000; 10:1527-1530.

15. Visentin B, Vekich JA, Sibbald BJ, Cavalli AL, Moreno KM, Matteo RG, Garland WA, Lu Y, Yu S, Hall HS, Kundra V, Mills GB, Sabbadini RA. Validation of an anti-sphingosine-1-phosphate antibody as a potential therapeutic in reducing growth, invasion, and angiogenesis in multiple tumor lineages. Cancer Cell. 2006; 9:225-238.

16. Quint K, Stiel N, Neureiter D, Schlicker HU, Nimsky C, Ocker M, Strik H, Kolodziej MA. The role of sphingosine kinase isoforms and receptors S1P1, S1P2, S1P3, and S1P5 in primary, secondary, and recurrent glioblastomas. Tumour Biol. 2014.

17. Abuhusain HJ, Matin A, Qiao Q, Shen H, Kain N, Day BW, Stringer BW, Daniels B, Laaksonen MA, Teo C, McDonald KL, Don AS. A metabolic shift favoring sphingosine 1-phosphate at the expense of ceramide controls glioblastoma angiogenesis. J Biol Chem. 2013; 288:37355-37364.

18. Anelli V, Gault CR, Cheng AB, Obeid LM. Sphingosine kinase 1 is up-regulated during hypoxia in U87MG glioma cells. Role of hypoxia-inducible factors 1 and 2. J Biol Chem. 2008; 283:3365-3375.

19. Riccitelli E, Giussani P, Di VC, Condomitti G, Tringali C, Caroli M, Galli R, Viani P, Riboni L. Extracellular sphingosine-1-phosphate: a novel actor in human glioblastoma stem cell survival. PLoS One. 2013; 8:e68229.

20. Annabi B, Lachambre MP, Plouffe K, Sartelet H, Beliveau R. Modulation of invasive properties of CD133+ glioblastoma stem cells: a role for MT1-MMP in bioactive lysophospholipid signaling. Mol Carcinog. 2009; 48:910-919.

21. Marfia G, Campanella R, Navone SE, Di VC, Riccitelli E, Hadi LA, Bornati A, de RG, Giussani P, Tringali C, Viani P, Rampini P, Alessandri G, et al. Autocrine/paracrine sphingosine-1-phosphate fuels proliferative and stemness qualities of glioblastoma stem cells. Glia. 2014.

22. Estrada-Bernal A, Palanichamy K, Ray CA, Van Brocklyn JR. Induction of brain tumor stem cell apoptosis by FTY720: a potential therapeutic agent for glioblastoma. Neuro Oncol. 2012; 14:405-415.

23. Van BJ, Letterle C, Snyder P, Prior T. Sphingosine-1phosphate stimulates human glioma cell proliferation through Gi-coupled receptors: role of ERK MAP kinase and phosphatidylinositol 3-kinase beta. Cancer Lett. 2002; 181:195-204.

24. Young N, Van Brocklyn JR. Roles of sphingosine-1phosphate (S1P) receptors in malignant behavior of glioma cells. Differential effects of S1P2 on cell migration and invasiveness. Exp Cell Res. 2007; 313:1615-1627.

25. Yoshida Y, Nakada M, Sugimoto N, Harada T, Hayashi Y, Kita D, Uchiyama N, Hayashi Y, Yachie A, Takuwa Y, Hamada J. Sphingosine-1-phosphate receptor type 1 regulates glioma cell proliferation and correlates with patient survival. Int J Cancer. 2010; 126:2341-2352.

26. Van Brocklyn JR, Young N, Roof R. Sphingosine-1phosphate stimulates motility and invasiveness of human glioblastoma multiforme cells. Cancer Lett. 2003; 199:53-60.

27. Takuwa N, Du W, Kaneko E, Okamoto Y, Yoshioka K, Takuwa Y. Tumor-suppressive sphingosine-1-phosphate receptor-2 counteracting tumor-promoting sphingosine- 
1-phosphate receptor-1 and sphingosine kinase 1-Jekyll Hidden behind Hyde. Am J Cancer Res. 2011; 1:460-481.

28. Johnson KR, Johnson KY, Becker KP, Bielawski J, Mao C, Obeid LM. Role of human sphingosine-1-phosphate phosphatase 1 in the regulation of intra- and extracellular sphingosine-1-phosphate levels and cell viability. J Biol Chem. 2003; 278:34541-34547.

29. Spiegel S, Milstien S. The outs and the ins of sphingosine-1phosphate in immunity. Nat Rev Immunol. 2011; 11:403-415.

30. Charles NA, Holland EC, Gilbertson R, Glass R, Kettenmann H. The brain tumor microenvironment. Glia. 2012; 60:502-514.

31. Kapitonov D, Allegood JC, Mitchell C, Hait NC, Almenara JA, Adams JK, Zipkin RE, Dent P, Kordula T, Milstien S, Spiegel S. Targeting sphingosine kinase 1 inhibits Akt signaling, induces apoptosis, and suppresses growth of human glioblastoma cells and xenografts. Cancer Res. 2009; 69:6915-6923.

32. Bektas M, Johnson SP, Poe WE, Bigner DD, Friedman HS. A sphingosine kinase inhibitor induces cell death in temozolomide resistant glioblastoma cells. Cancer Chemother Pharmacol. 2009; 64:1053-1058.

33. Van Brocklyn JR, Jackson CA, Pearl DK, Kotur MS, Snyder PJ, Prior TW. Sphingosine kinase-1 expression correlates with poor survival of patients with glioblastoma multiforme: roles of sphingosine kinase isoforms in growth of glioblastoma cell lines. J Neuropathol Exp Neurol. 2005; 64:695-705.

34. Pyne NJ, Pyne S. Selectivity and specificity of sphingosine 1-phosphate receptor ligands: "off-targets" or complex pharmacology? Front Pharmacol. 2011; 2:26.

35. Sanna MG, Wang SK, Gonzalez-Cabrera PJ, Don A, Marsolais D, Matheu MP, Wei SH, Parker I, Jo E, Cheng WC, Cahalan MD, Wong CH, Rosen H. Enhancement of capillary leakage and restoration of lymphocyte egress by a chiral S1P1 antagonist in vivo. Nat Chem Biol. 2006; 2:434-441.

36. Salomone S, Waeber C. Selectivity and specificity of sphingosine-1-phosphate receptor ligands: caveats and critical thinking in characterizing receptor-mediated effects. Front Pharmacol. 2011; 2:9.

37. Zhang L, Wang H, Zhu J, Ding K, Xu J. FTY720 reduces migration and invasion of human glioblastoma cell lines via inhibiting the PI3K/AKT/mTOR/p70S6K signaling pathway. Tumour Biol. 2014; 35:10707-10714.

38. Louis DN, Ohgaki H, Wiestler OD, Cavenee WK, Burger PC, Jouvet A, Scheithauer BW, Kleihues P. The 2007 WHO classification of tumours of the central nervous system. Acta Neuropathol. 2007; 114:97-109. 